\title{
Comparison of dike intrusions in an incipient seafloor-spreading segment in Afar, Ethiopia: Seismicity perspectives
}

\author{
Manahloh Belachew, ${ }^{1,2}$ C. Ebinger, ${ }^{1}$ D. Coté, ${ }^{1}$ D. Keir, ${ }^{3}$ J. V. Rowland, ${ }^{4}$ \\ J. O. S. Hammond, ${ }^{5}$ and A. Ayele ${ }^{2}$ \\ Received 3 August 2010; revised 28 December 2010; accepted 15 March 2011; published 24 June 2011.
}

[1] Oceanic crust is accreted through the emplacement of dikes at spreading ridges, but the role of dike intrusion in plate boundary deformation during continental rupture remains poorly understood. Between 2005 and 2009 the $70 \mathrm{~km}$ long Dabbahu-Manda Hararo rift segment in Ethiopia has experienced 14 large volume dike intrusions, 9 of which were recorded on temporary seismic arrays. A detailed comparison of the seismic characteristics of the seismically monitored dikes is presented with implications for dike intrusion processes and magmatic plumbing systems. All of the migrating swarms of earthquakes started from a $<5 \mathrm{~km}$ radius zone at the middle of the Dabbahu-Manda Hararo segment, and traveled northward and southward along the rift axis. Small magnitude earthquakes associated with the margins of the propagating dike tips are followed by the largest magnitude, primarily low-frequency earthquakes. The seismic moment distributions show $>80 \%$ of energy is released during the propagation phase, with minimal seismic energy release after the dike propagation ceases. We interpret that faulting and graben formation above the dikes occurs hours after the passage of the dike tip, coincident with the onset of low-frequency earthquakes. Dike lengths show no systematic reduction in length with time, suggesting that topographic loading and stress barriers influence dike length, as well as changes in tectonic stress. The propagation velocities of all the dikes follow a decaying exponential. Northward propagating dikes had faster average velocities than those that propagated southward, suggesting preconditioning by the 2005 megadike, or ongoing heating from a subcrustal magma source north of the midsegment.

Citation: Belachew, M., C. Ebinger, D. Coté, D. Keir, J. V. Rowland, J. O. S. Hammond, and A. Ayele (2011), Comparison of dike intrusions in an incipient seafloor-spreading segment in Afar, Ethiopia: Seismicity perspectives, J. Geophys. Res., 116, B06405, doi:10.1029/2010JB007908.

\section{Introduction}

[2] About two thirds of Earth's crust is created at divergent plate boundaries [e.g., Kidd, 1977; Delaney et al., 1998; Macdonald, 1998]. Exposures of sheeted dikes in ophiolite complexes and the seismically identified layer $2 \mathrm{~b}$ show the importance of dike intrusions for crustal accretion [e.g., Macdonald, 1998]. However, such processes are often undetected mainly due to lack of access to the active oceanic rifts and our ability to detect signals remotely. Studies of subaerial volcanotectonic rifting processes, however, have

\footnotetext{
${ }^{1}$ Department of Earth and Environmental Sciences, University of Rochester, Rochester, New York, USA.

${ }^{2}$ Inistitute of Geophysics, Space Science and Astronomy, Addis Ababa University, Addis Ababa, Ethiopia.

${ }^{3}$ School of Earth and Environment, University of Leeds, Leeds, UK.

${ }^{4}$ School of Environment, University of Auckland, Auckland, New Zealand.

${ }^{5}$ Department of Earth Science, University of Bristol, Bristol, UK.
}

Copyright 2011 by the American Geophysical Union. 0148-0227/11/2010JB007908 contributed significantly to the understanding of dike intrusion related processes [Björnsson et al., 1977; Abdallah et al., 1979; Einarsson and Brandsdóttir, 1980; Tryggvason, 1984; Klein et al., 1987; Einarsson, 1991; Fox et al., 1995; Rubin et al., 1998; Dziak et al., 2004; Doubre et al., 2007a; Traversa and Grasso, 2009]. In most cases dike intrusions are characterized by deflation-inflation sequences of the dike feeder chamber and associated subsidence-uplift cycles above it and by lateral migration of earthquake swarms as magma is removed from the chamber and intruded into the rift [Moore and Krivoy, 1964; Brandsdóttir and Einarsson, 1979; Einarsson, 1991; Rubin et al., 1998; Toda et al., 2002]. Elastic models of propagation of fluid-filled cracks show fault slip ahead of a laterally propagating dike and graben formation above it account for the majority of seismicity [e.g., Rubin and Pollard, 1988; Rubin, 1992; Rubin and Gillard, 1998]. Such models require an ambient stress distribution that is near failure, and existing fractures that extend to the dike plane at depth. Seismicity during dike intrusions is also attributed to the volumetric response of the solid matrix to the emplacement of magma [e.g., Traversa et al., 2010]. 
Geodetic and seismic observations in different rift settings and on basaltic volcanoes also support these modeling results [e.g., Rubin and Pollard, 1988; Brandsdóttir and Einarsson, 1979; Rubin et al., 1998; Traversa and Grasso, 2009]. The temporal coincidence between deflation signals and migrating earthquakes observed in some rifts suggest that dike widening stops when deflation stops at the source [e.g., Einarsson, 1991; Yamaoka et al., 2005].

[3] Within tectonic rifts, dike feeder zones are located within the crust, and dikes are injected along the rift axis perpendicular to the rift opening direction. The 20 dike intrusions and fissural eruptions, for instance, between 1975 and 1984 in Krafla, Iceland were fed from a shallow magma chamber located at $\sim 3 \mathrm{~km}$ depth beneath the Krafla caldera [Einarsson, 1978; Brandsdóttir et al., 1997], which itself was probably fed from a subcrustal source [Björnsson, 1985; de Zeeuw-van Dalfsen et al., 2004]. Shallow axial magma chambers were also identified beneath the Asal rift [Doubre et al., 2007b], on the Juan de Fuca Ridge [Bohnenstiehl et al., 2004] and beneath Kilauea caldera [Owen et al., 2000; Cervelli et al., 2002].

[4] Magma breaches the walls of a chamber and propagates along the rift when the magma chamber pressure reaches a threshold value, commonly known as breakout pressure [Rubin, 1995; Buck et al., 2006]. Among the factors that control propagation of dikes are the rate of pressure drop in the source, stress level to overcome resistance at the dike tip, the hydraulic connection between the source and dike, regional tectonic stress level, viscous resistance of the magma and presence of stress barriers [Delaney and Pollard, 1982; Lister and Kerr, 1991; Rubin, 1995; Segall et al., 2001; Behn et al., 2006; Buck et al., 2006; Rivalta and Segall, 2008]. Buck et al. [2006] used an elastic model and showed the evolution of tectonic stress due to successive dike intrusions and the decrease in magma chamber pressure due to magma withdrawal control the pattern of multiple dike intrusions. By assuming a constant breakout pressure, their model predicts intrusion of a sequence of dikes propagating in one direction followed by intrusions in the opposite direction. In each sequence the first dike is the longest and subsequent intrusions propagate shorter distances. The model also predicts that fissural eruptions occur in the vicinity of the feeder zone toward the end of the rifting episode, presumably as tectonic stress is relieved. Such a dike intrusion pattern was supported by data from the 1975-1984 Krafla, Iceland rifting episode [e.g., Tryggvason, 1984; Einarsson, 1991], and was also observed at different volcanic settings [Takada, 1997]. Models of the time history of individual dikes show that the propagation velocity of dikes depends on the pressure drop in the chamber and the inherent rigidity of the rocks surrounding the magma chamber [Rivalta and Segall, 2008; Rivalta, 2010]. Moreover, dike size and growth, and the evolution of the stress field due to the preceding intrusion also affect propagation velocities [Hamling et al., 2010; Traversa et al., 2010].

[5] Since September 2005 the Dabbahu-Manda Hararo (DMH) rift segment within the Afar Depression experienced 14 major dike intrusions, and three of these were associated with fissural eruptions [e.g., Hamling et al., 2009; Ebinger et al., 2010; Ferguson et al., 2010]. Seismicity accompanying the initial and largest dike intrusion recorded on regional stations was presented by Ayele et al. [2009], and two subsequent dikes recorded on a sparse temporary array and a permanent station by Keir et al. [2009]. Hamling et al. [2009] and Grandin et al. [2010a] use surface deformation patterns to predict magma volumes, dike dimensions and magma source zones for the dike intrusions, but without constraints from seismicity data. Ebinger et al. [2010] summarized briefly the onset/end times and migration directions of the seismicity associated with the dikes between 2007 and 2009 but left the detailed comparison for this paper. We present, for the first time, detailed analyses of the seismicity patterns accompanying Dikes 7-13 recorded on a 44-station seismic network, and interpret them in the growing body of structural and geodetic studies from this region, and of models of rift zone dike intrusions worldwide.

[6] In this paper we compare and contrast the detailed temporal and spatial distribution of intense seismic activity from 7 of the 14 dike intrusions that took place between 2007 and 2009, and were detected on the same 44-station seismic array. We include seismicity patterns for Dikes 2 and 3 [Keir et al., 2009] and parameters from elastic models of InSAR deformation patterns [Hamling et al., 2009; Hamling, 2010] in our effort to understand the DabbahuManda Hararo dike sequences. In addition, interdike seismicity distribution is presented. Our aim is to gain insight into the timing and dynamics of the magma intrusion process, feeder zone(s) location, repeat intervals of the dike intrusions, rates and directions of propagation, and faulting processes above and ahead of the propagating dikes, and to evaluate the relative importance of factors controlling dike lengths. These interpretations of the multiple dike intrusion episodes within the Dabbahu-Manda Hararo segment provide an unprecedented opportunity to understand how magma is emplaced, and to test and refine models for the along-axis segmentation of the incipient slow-spreading seafloor spreading center in Afar that shares many morphological characteristics of slow-spreading mid-ocean ridges [e.g., Hayward and Ebinger, 1996]. Thus, studies of this rift segment provide fundamental constraints on the initiation and maintenance of mid-ocean ridge segments, and the role of intense rifting episodes in the development of rift faults.

\section{Tectonic Setting}

[7] The $\sim 300 \mathrm{~km}$ wide Afar Depression marks the zone of linkage between the Gulf of Aden, Red Sea, and Main Ethiopian Rift systems [McKenzie et al., 1970] (Figure 1). The Red Sea and Aden rifts separate Arabia from Africa; rifting has progressed to seafloor spreading along the length of the Gulf of Aden, and in the southern Red Sea north of 14 N [e.g., Manighetti et al., 1997; Cochran, 1983; Bellahsen et al., 2003; d'Acremont et al., 2005] (Figure 1). South of $14^{\circ} \mathrm{N}$, the Red Sea narrows, and a parallel zone of extension and magmatism lies within the Afar depression [Barberi and Varet, 1977; Manighetti et al., 1998; Ayele et al., 2007b; ArRajehi et al., 2010; McClusky et al., 2010]. Since $3 \mathrm{Ma}$, rifting in the Afar Depression became localized within the $\sim 60 \mathrm{~km}$ long Quaternary magmatic segments with aligned cones, small offset faults and fissures marking the locus of active deformation along the length of the MER, southern Red Sea, and westernmost Gulf of Aden rifts [Mohr, 1967; Barberi and Varet, 1977; Hayward and Ebinger, 1996; 


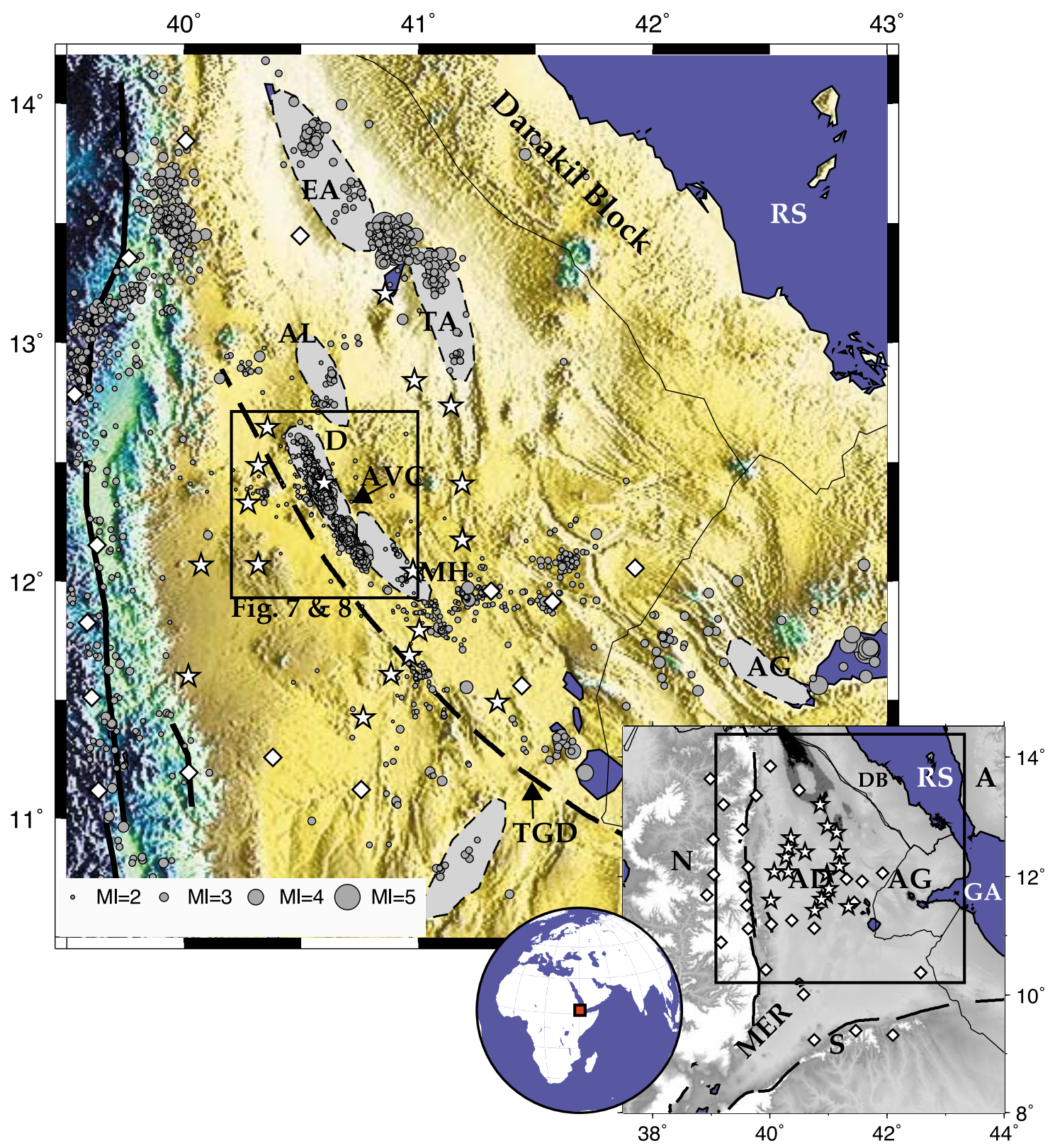

Figure 1. Seismicity of the Afar depression (gray circles) recorded between 2007 and 2009 on the combined IRIS-PASSCAL (stars) and Seis-UK (diamonds) seismic network shown the in the inset. Gray circles represent earthquakes. Heavy black lines show Oligocene border faults of the southern Red Sea, and the heavy broken line represents the Tendaho Goba'ad Discontinuity (TGD) marking the East African rift-Red Sea rift intersection. The thin lines are national boundaries. Gray filled regions with dashed line edges indicate the locus of Quaternary faulting and magmatism: AL, Alayta; AVC, Ado'Ale Volcanic Complex; D, Dabbahu; EA, Ert'Ale; MH, Manda-Hararo; TA, Tat'Ale; AG, Asal-Ghoubbet magmatic segments. A is Arabian Plate; DB is the Danakil Block; $\mathrm{S}$ is Somalian plate, GA is Gulf of Aden; MER, Main Ethiopian Rift; N, Nubian Plate; RS, Red Sea.

Manighetti et al., 2001; Wolfenden et al., 2005]. The mafic thin crust, high crustal velocities, and low upper mantle velocities compared to normal continental crust show the Afar crust has been heavily intruded and underplated since at least $30 \mathrm{Ma}$ [Berckhemer et al., 1975; Makris and Ginzburg, 1987].

[8] The $\sim 70 \mathrm{~km}$ long Dabbahu-Manda Hararo (DMH) rift segment, where the 2005 - present volcanotectonic rifting episode is taking place, comprises the Dabbahu segment at its northern limit and the northern part of the Manda Hararo rift, including the Ado'Ale Volcanic Complex [Barberi et al., 1974; Varet, 1978; Hayward and Ebinger, 1996] (Figure 1). The Ado'Ale Volcanic Complex (AVC) is a WSW-ENE trending chain of heavily faulted felsic volcanoes straddling both sides of the rift. The rifted volcanic edifices on either side of the midsegment have ages ranging between $\sim 0.3 \mathrm{Ma}$ in the rift center and $1.5 \mathrm{Ma}$ on the eastern flank [Lahitte et al., 2003]. This indicates the segment has been maintained over 


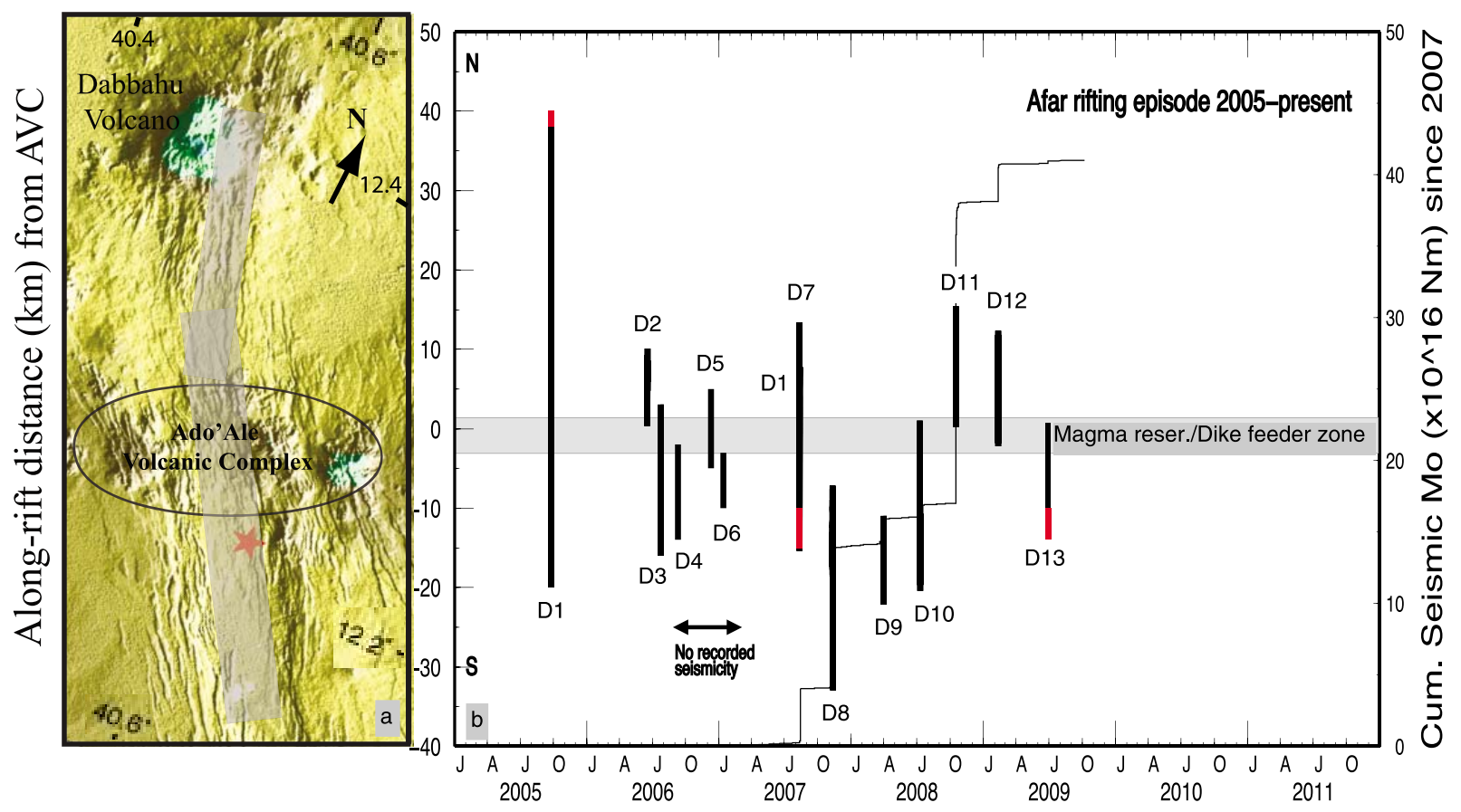

Figure 2. (a) DEM plot of the Dabbahu-Manda Hararo rift segment. The shaded region shows the rift axis intruded by the 13 dikes between 2005 and 2009. (b) Along-axis distance versus time plot of the dike intrusions and fissural eruptions for the Dabbahu-Manda Hararo rift segment since 2005. Vertical axis represents distance along the rift segment measured from $12.3^{\circ} \mathrm{N}$ and $40.6^{\circ} \mathrm{E}$ at $\mathrm{AVC}$. The black lines indicate the along-axis extent of seismicity for Dikes 2, 3 and 7-13, and length estimates from Hamling et al. [2009] and Wright et al. [2006] for Dikes 1, 4-6. The 14th intrusion that took place in May 2010 is not shown here. Red lines denote dike intrusions with fissural eruptions. Location of the midcrustal to lower crustal magma reservoir feeding the dikes in the Dabbahu-Manda Hararo segment is indicated by horizontal shaded region. The thin gray line shows the cumulative seismic moment between March 2007 and October 2009. The time period where there were no recording seismic stations in Afar is shown by the double-headed arrow.

many rifting cycles of $\sim 30,000-50,000$ years, as estimated from young flows resurfacing part of the central rift valley [Williams et al., 2009]. Thus, the magma plumbing system has existed beneath the region for at least $1.5 \mathrm{My}$, the age of the Ado'Ale Volcanic Complex (AVC) [Lahitte et al., 2003]. From north to south long the DMH rift segment, normal fault orientations change from N-S to NNW-SSE, and some $<10 \mathrm{~km}$ long faults show 3-5 m of displacement after the 2005 megadike intrusion [Rowland et al., 2007; Grandin et al., 2009], demonstrating the importance of fault slip in dike seismicity patterns.

\section{Dike Intrusions Between 2005 and 2007}

[9] The current rifting cycle in the DMH rift segment was preceded by a few regionally recorded earthquakes starting from 14 September 2005, followed by an intense swarm of slowly southward migrating seismic activity on 20 24 September [Ayele et al., 2009]. This volcanic unrest may have triggered the intrusion of $\sim 2.5 \mathrm{~km}^{3}$ of magma along the $\sim 70 \mathrm{~km}$ long DMH rift segment [Wright et al., 2006; Ayele et al., 2009]. The swarm of earthquakes then jumped to the midsegment on 24 September and migrated mainly to the north. Models of surface deformation indicated that the September 2005 megadike was sourced beneath the Dabbahu and Gab'ho volcanoes [Wright et al., 2006], as well as a deeper magma reservoir beneath the segment center within the AVC [Grandin et al., 2009]. Ayele et al. [2009] used earthquake migration patterns to confirm a magma source beneath the DMH segment center. Seismicity patterns recorded on a temporary array deployed 2 weeks after the dike intrusion illuminated a $<3 \mathrm{~km}$ wide zone from the AVC northward, and illuminated multiple shallow crustal magma reservoirs and conduits beneath the Dabbahu volcanic complex [Ebinger et al., 2008].

[10] The September megadike intrusion was followed by intrusion of a relatively smaller volume, June 2006 dike (Dike 2) from the midsegment [Hamling et al., 2009; Keir et al., 2009; Grandin et al., 2010a] (Figure 2). Keir et al. [2009] used seismicity and geodetic data to show that Dikes 2 and 3 were fed from a chamber beneath the midsegment of the rift, and that dike opening coincides with maximum seismic moment release. Unfortunately, Dikes 4-6 occurred during a gap in local-scale seismic monitoring, and no constraints on the detailed timing of seismicity patterns of these dike intrusion episodes are available. Hamling et al. [2009] modeled InSAR data acquired over a 35 day period spanning the intrusion of Dikes $2-8$, assuming a source at the midsegment and two conjugate $65^{\circ}$ dipping faults which extend to a depth of $2 \mathrm{~km}$. They obtained average dike lengths of $\sim 10 \mathrm{~km}$, and dike widths of $0.5-2 \mathrm{~m}$ (Table 1). The deformation patterns showed that the dikes intruded the 
Table 1. Parameters Determined Using Geodetic Data ${ }^{a}$

\begin{tabular}{lccccc}
\hline Dike & Geodetic Moment $\left(\times 10^{18} \mathrm{Nm}\right)$ & Volume $\left(\mathrm{km}^{3}\right)$ & Length $(\mathrm{km})$ & Width $(\mathrm{m})$ & Depth $(\mathrm{km})$ \\
\hline 2 & 5.44 & $0.12 \pm 0.01$ & $8.2 \pm 0.4$ & $2.2 \pm 0.2$ & $0-10$ \\
3 & 3.25 & $0.042 \pm 0.017$ & $9.9 \pm 0.3$ & $1.1 \pm 0.1$ & $0-6$ \\
7 & 2.41 & $0.048 \pm 0.001$ & $9.1 \pm 0.1$ & $2.4 \pm 0.1$ & $0-3$ \\
8 & 6.01 & $0.15 \pm 0.01$ & $11.6 \pm 0.3$ & 0.1 & $0.9 \pm 0.1$ \\
9 & 3.72 & $0.088 \pm 0.02$ & $8.9 \pm 2.1$ & $1.3 \pm 0.2$ & 0.10 \\
10 & 3.21 & $0.066 \pm 0.02$ & $9.7 \pm 0.7$ & $1.5 \pm 0.1$ & $1-9$ \\
11 & 7.88 & $0.17 \pm 0.001$ & $10.3 \pm 0.2$ & 0.1 & 0.9 \\
12 & 3.02 & $0.077 \pm 0.005$ & $9.2 \pm 0.2$ & 0.1 & $0-5$ \\
\hline
\end{tabular}

${ }^{\mathrm{a}}$ Hamling et al. [2009] and Hamling [2010].

rift to the north and south of the AVC. The combined analysis of the available data indicate that a central segment magma reservoir feeds dikes and maintains the along-axis segmentation of this late stage continental rift [Rowland et al., 2007; Keir et al., 2009].

\section{Data}

[11] As part of the collaborative Afar Consortium project, which involves U.S., UK and Ethiopian universities, 44 IRIS-PASSCAL and SEIS-UK 3-component Guralp CMG40T, CMG-3T and CMG-3ESP broadband seismometers were deployed and operated between March 2007 and October 2009 across a $\sim 350 \mathrm{~km} \times 365 \mathrm{~km}$ region within the Afar Depression and on the eastern side of the Ethiopian plateau (Figure 1). Sample rate was set to $50 \mathrm{~Hz}$, and a detection threshold of $\sim 1.9 \mathrm{M}_{\mathrm{L}}$ is obtained from the power law cumulative frequency-magnitude distribution [Gutenberg and Richter, 1956] (Figure S1 of the auxiliary materials). ${ }^{1}$ Within the Afar Depression, due to the remoteness of the region, temporary seismic stations could only be deployed in villages and guarded government facilities, preventing deployments above the presumed intrusion zone. However, the remoteness contributed to the low level of high-frequency cultural noise $(>1 \mathrm{~Hz})$ observed on most of the stations. Most of the stations operated continuously despite the extremely harsh field conditions. Four of these stations reoccupied locations from the 2005-2006 experiment [Ebinger et al., 2008; Keir et al., 2009].

\section{Methods}

[12] Continuous waveforms from the combined PASSCAL and SEIS-UK arrays were manually scanned and analyzed using the analysis program Seismic Handler Motif (SHM) [Stammler, 1993]. P and S wave arrival times were picked manually on Butterworth filtered $(0.6-15 \mathrm{~Hz})$ vertical and horizontal components, respectively. $\mathrm{P}$ phase arrival times were assigned quality factors of $0,1,2$ or 3 according to estimated measurement errors of $0.05 \mathrm{~s}, 0.1 \mathrm{~s}, 0.15 \mathrm{~s}$, and $0.3 \mathrm{~s}$, respectively. $\mathrm{S}$ wave quality factors of $0,1,2$, and 3 were assigned to arrivals with estimated measurement errors of $0.1 \mathrm{~s}, 0.175 \mathrm{~s}, 0.25 \mathrm{~s}$, and $0.3 \mathrm{~s}$, respectively. A total of $45272 \mathrm{P}$ and $39867 \mathrm{~S}$ wave arrival times were picked from $\sim 5320$ local earthquakes recorded from within the Afar Depression during the two and a half year operation period

\footnotetext{
${ }^{1}$ Auxiliary materials are available in the HTML. doi:10.1029/ 2010JB007908.
}

of the network. Almost half of the earthquakes occurred during the dike intrusion episodes within the DabbahuManda Hararo segment (Figure 1).

[13] All events were initially located using the absolute location program Hypoinverse2000 [Klein, 2002]. A 3-layer one-dimensional $\mathrm{P}$ wave velocity model of Jacques et al. [1996] derived from earlier seismic refraction studies in Afar [Berckhemer et al., 1975; Ruegg, 1975; Makris and Ginzburg, 1987] and Vp/Vs ratio of 1.8 determined from regression of travel times were used for the initial earthquake locations. Earthquakes recorded on 4 or more stations and with 6 or more $\mathrm{P}$ and/or S arrival time readings are used for location. During location of the events arrival times were given weights of full (1), 0.75, 0.5, and 0.25 for $\mathrm{P}$ wave readings with quality factors of $0,1,2$, and 3 , respectively. $\mathrm{S}$ waves were given half weighting relative to $\mathrm{P}$ waves of the same quality factor.

[14] A new minimum 1-D P wave velocity model and station corrections were determined by simultaneously relocating earthquakes and inverting for velocity structure with VELEST [Kissling et al., 1995]. Only earthquakes with twelve or more $\mathrm{P}$ arrivals, and an azimuthal gap of less than $180^{\circ}$ were used to invert for the 1-D P wave velocity model. 610 earthquakes satisfied the selection criteria and were relocated. Hypocenter accuracy of the earthquakes and stability of the velocity model were tested by randomly shifting hypocenters and considering higher and lower velocities (Figure S2). From these tests we estimate hypocenter accuracy for earthquakes of about $\pm 1000 \mathrm{~m}$ in horizontal directions and $\pm 3000 \mathrm{~m}$ in depth. Only earthquakes related to the dike intrusion episodes in the $\mathrm{DMH}$ segment are considered here.

[15] Magnitude for all the earthquakes is estimated using the local magnitude scale and distance correction terms for the Main Ethiopian Rift [Keir et al., 2006]. Maximum zeroto-peak body wave amplitudes are measured on simulated Wood-Anderson horizontal displacement seismograms. In addition, the Mo-mb scale determined specifically for the region including the DMH rift system (Region IV) [Hofstetter and Beyth, 2003] is used to estimate the seismic moments for the earthquakes and cumulative seismic moments for the dike intrusions. The $\mathrm{b}$ values for each dike intrusion related swarms are estimated using the maximum likelihood approach [Aki, 1965], and magnitude completeness values are determined from the frequency-magnitude distribution [Gutenberg and Richter, 1956] (Table S1).

[16] The data set reveals a range of volcanotectonic earthquake types, including low-frequency events with long codas associated with scattering and high attenuation [e.g., 
Table 2. Dike Parameters Determined From Earthquake Swarms Associated With the Intrusions ${ }^{\mathrm{a}}$

\begin{tabular}{|c|c|c|c|c|c|c|c|c|c|}
\hline Dike & Onset Time & $\begin{array}{l}\text { Migration } \\
\text { Duration } \\
\text { (h) }\end{array}$ & $\begin{array}{l}\text { Postmigration } \\
\text { Swarm Duration } \\
\text { (h/days) }\end{array}$ & $\begin{array}{l}\text { Migration } \\
\text { Distance } \\
(\mathrm{km})\end{array}$ & $\begin{array}{c}\text { Swarm } \\
\text { Along-Axis } \\
\text { Length }(\mathrm{km})\end{array}$ & $\begin{array}{c}\text { Seismic } \\
\text { Moment } \\
\left(\times 10^{15} \mathrm{Nm}\right)\end{array}$ & $\begin{array}{c}\text { Average } \\
\text { Migration } \\
\text { Rate }(\mathrm{m} / \mathrm{s})\end{array}$ & $\begin{array}{l}\text { Earthquake } \\
\text { Depth } \\
\text { Range }(\mathrm{km})\end{array}$ & $\begin{array}{l}\text { Seismic Moment } \\
\text { of Migrating } \\
\text { Swarm (\%) }\end{array}$ \\
\hline 2 & 12:39 (17-Jun., 2006) & 4 & $120 / 5$ & 10 & 10 & 187 & 0.5 & - & 97.09 \\
\hline 3 & 20:00 (25 Jul., 2006) & 6 & - & 15 & 15 & 1.6 & 0.75 & - & - \\
\hline 7 & 23:48 (11 Aug., 2007) & - & - & - & 20 & 1.293 & - & $0-8$ & - \\
\hline 8 & 16:04 (11-Nov., 2007) & 44 & $90 / 3.75$ & 24 & 25 & 102.7 & 0.24 & $0-8$ & 82.8 \\
\hline 9 & 3:38 (31-Mar., 2008) & 19 & $60 / 2.5$ & 12 & 15 & 15.63 & 0.16 & $3-10$ & 88.17 \\
\hline 10 & 08:24 (9-July., 2008) & 30 & $14 / 0.58$ & 20 & 23 & 8.247 & 0.26 & $0-8$ & 94.79 \\
\hline 11 & 07:15 (17-Oct., 2008) & 8 & $50 / 2.08$ & 15 & 18 & 178.1 & 0.58 & $0-9$ & 77.08 \\
\hline 12 & 17:11 (11-Feb., 2009) & 7 & $46 / 1.875$ & 12 & 15 & 27.01 & 0.45 & $0-9$ & 96.08 \\
\hline 13 & 12:39 (17-Jun., 2009) & - & - & - & 18 & 1.178 & - & $0-9$ & - \\
\hline
\end{tabular}

${ }^{a}$ Migration distances and swarm along-axis lengths represent along-rift lengths covered by the earthquake epicenters. Parameters for Dikes 2 and 3 are from Keir et al. [2009].

Coté et al., 2010]. During dike intrusion events, we also note a class of hybrid earthquakes with impulsive first arrivals showing monotonic spectral peaks at $<2 \mathrm{~Hz}$. Spectral analysis is performed to distinguish low-frequency earthquakes with one or more spectral peaks below $5 \mathrm{~Hz}$, following the classification of Lahr et al. [1994] and McNutt [2005]. Waveforms of vertical traces were high-pass filtered with a 4th order Butterworth filter at $0.005 \mathrm{~Hz}$ in a time window of $10 \mathrm{~s}$ before and $50 \mathrm{~s}$ after the estimated $\mathrm{P}$ arrival to remove DC offsets. Spectral analysis of each earthquake at $0.1 \mathrm{~Hz}$ resolution was used to categorize low-frequency earthquakes, as outlined by Coté et al. [2010] (Figure S3). Earthquakes with maximum energy in bins less than $2 \mathrm{~Hz}$, including low-frequency hybrid events, are considered lowfrequency events. Those events with peak frequency $\geq 2 \mathrm{~Hz}$ are referred to as "tectonic earthquakes". The spectral analysis was performed for each station and each earthquake to avoid effects of attenuation and noise on the spectra, both of which are significant along some raypaths, particularly those along the rift axis [Coté et al., 2010]. Earthquakes from the dike swarms were recorded by stations located on either side of the intrusion zone, allowing the intruded area to be eliminated as a source of attenuation, and confirming their lowfrequency source. The anomalous low-frequency content, therefore, is seen as a result of the source mechanism(s) generating these earthquakes.

\section{Observations}

[17] In this section observations of the seismicity from the 7 dike intrusions recorded by the combined U.S.-UK seismic network that operated between 2007 and 2009 are outlined. For convenience, in Table 1 we summarize the dike length, depth range, magma volume, and geodetic moment estimated from inverse models of InSAR and GPS data [Hamling et al., 2009; Hamling, 2010]. Table 2 summarizes seismicity constraints on dike length, duration of propagation, propagation velocity, and seismic moment release from Dikes 7-13, and includes constraints of Dikes 2 and 3 from Keir et al. [2009] for comparison. Specifically, the temporal and spatial distributions of earthquakes are presented in detail as constraints on the magma sources and dike intrusion processes, with implications for timing and dynamics of the dike intrusion processes and faulting accompanying dike intrusions. There were two sequences of intrusion; 4 of the dikes intruded the rift to the south of AVC and 2 dikes propagated to the north of the AVC. One of intrusions resulted in seismicity distributed both to the north and south of AVC. Two of the dikes produced fissural eruptions to the south of the AVC [Ferguson et al., 2010]. All times are in UTC, and distances are measured along the rift axis from $12.3^{\circ} \mathrm{N}$ and $40.6^{\circ} \mathrm{E}$. Average migration velocities are estimated by projecting the epicenters along an average along-axis propagation line inferred from the seismicity distribution. The slope of the distance versus time plot for a given subset of events is considered as the average migration velocity. Subsets of events are chosen from the distance-time plots with clear change in slope.

\subsection{The 11-13 August 2007 Intrusion and Fissural Eruption (Dike 7)}

[18] A localized seismic swarm started at 23:29 on August 11 with a tectonic earthquake of $1.8 \mathrm{M}_{\mathrm{L}}$ near the center of the rift segment (Figure 3a). Activity continued with very small magnitude earthquakes recorded only at a station $\sim 40 \mathrm{~km}$ from the rift resulting in an apparent gap of located events until the activity started to increase around 09:00 on August 12. The first low-frequency event was recorded at 09:09 (Figure 4a). Around 11:00 the number of earthquakes increased to a maximum of 19 events per hour (Figure 5a) with more earthquakes north of AVC than in the south where the basaltic fissural eruption occurred [Ferguson et al., 2010] (Figure 3a). The first thermal alert from Moderate Resolution Imaging Spectroradiometer (MODIS) was recorded at 20:15 on 12 August, hours after the seismicity level decreased (Figures $3 \mathrm{a}$ and $4 \mathrm{a}$ ). Depths of earthquakes range from the surface to $\sim 8 \mathrm{~km}$ (Figure 6a). Local pastoralists observed a sudden, southward propagating cracking noise on 12th of August and first noticed the fissural eruption as 'fire' around 14:30 on the 13th. The eruption took place along an $\sim 5 \mathrm{~km}$ fissure and covered $\sim 200 \mathrm{~m}$ wide zone [Yirgu, 2007]. Taking $2 \mathrm{~m}$ of average flow thickness the erupted volume is estimated to be $<0.002 \mathrm{~km}^{3}$ [e.g., Hamling et al., 2009]. The erupted rocks are transitional from subalkaline to alkaline hypersthene-normative basalt lavas, with $\mathrm{SiO}_{2}$ contents of 48-49 wt.\% [Ferguson et al., 2010], indicating a relatively low viscosity.

[19] About half of the located events are low-frequency earthquakes and they occurred both to the north and to the south of the AVC along the rift (Figure 4a). A few lowfrequency earthquakes were recorded on 13 August to the 

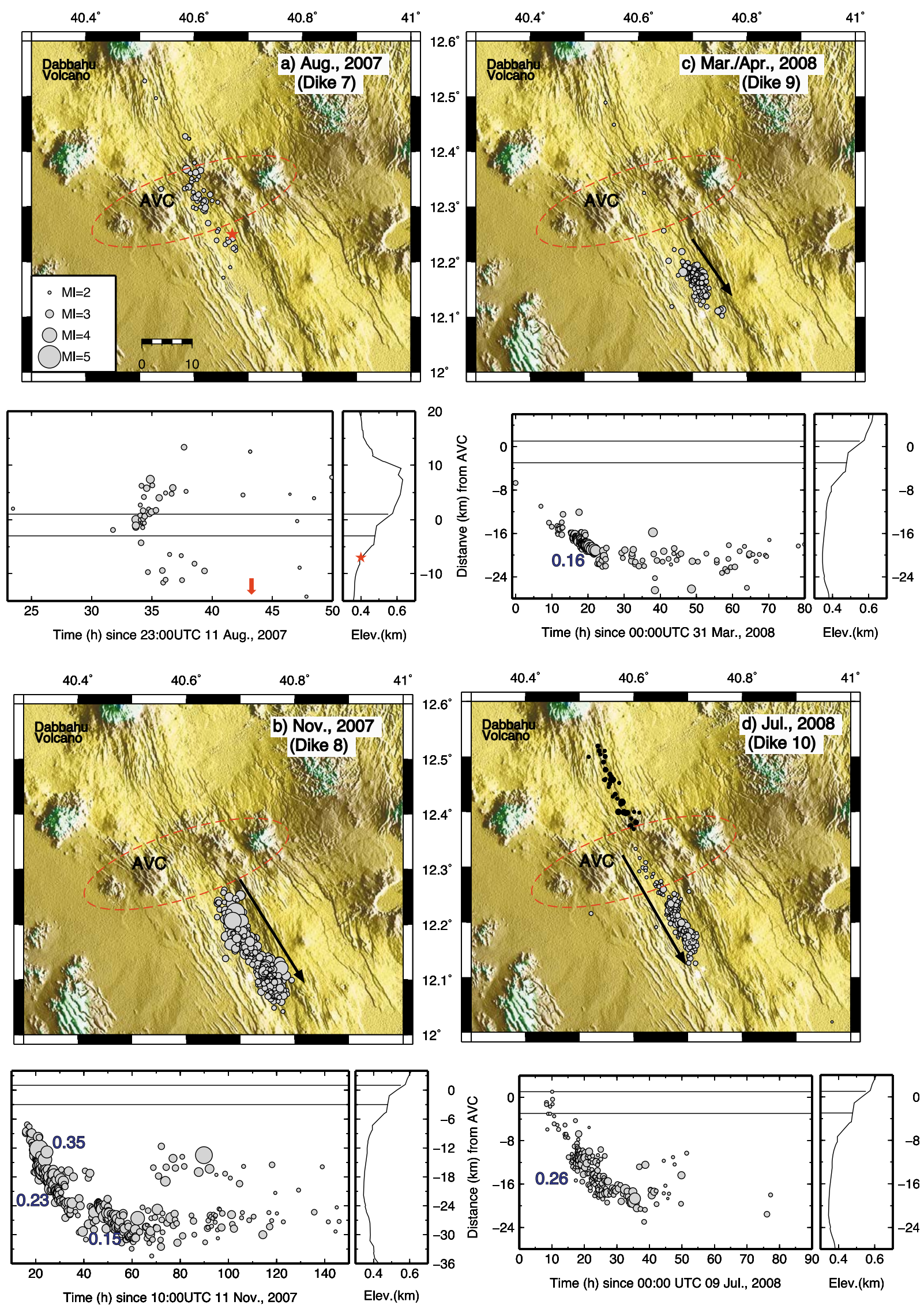

Figure 3 

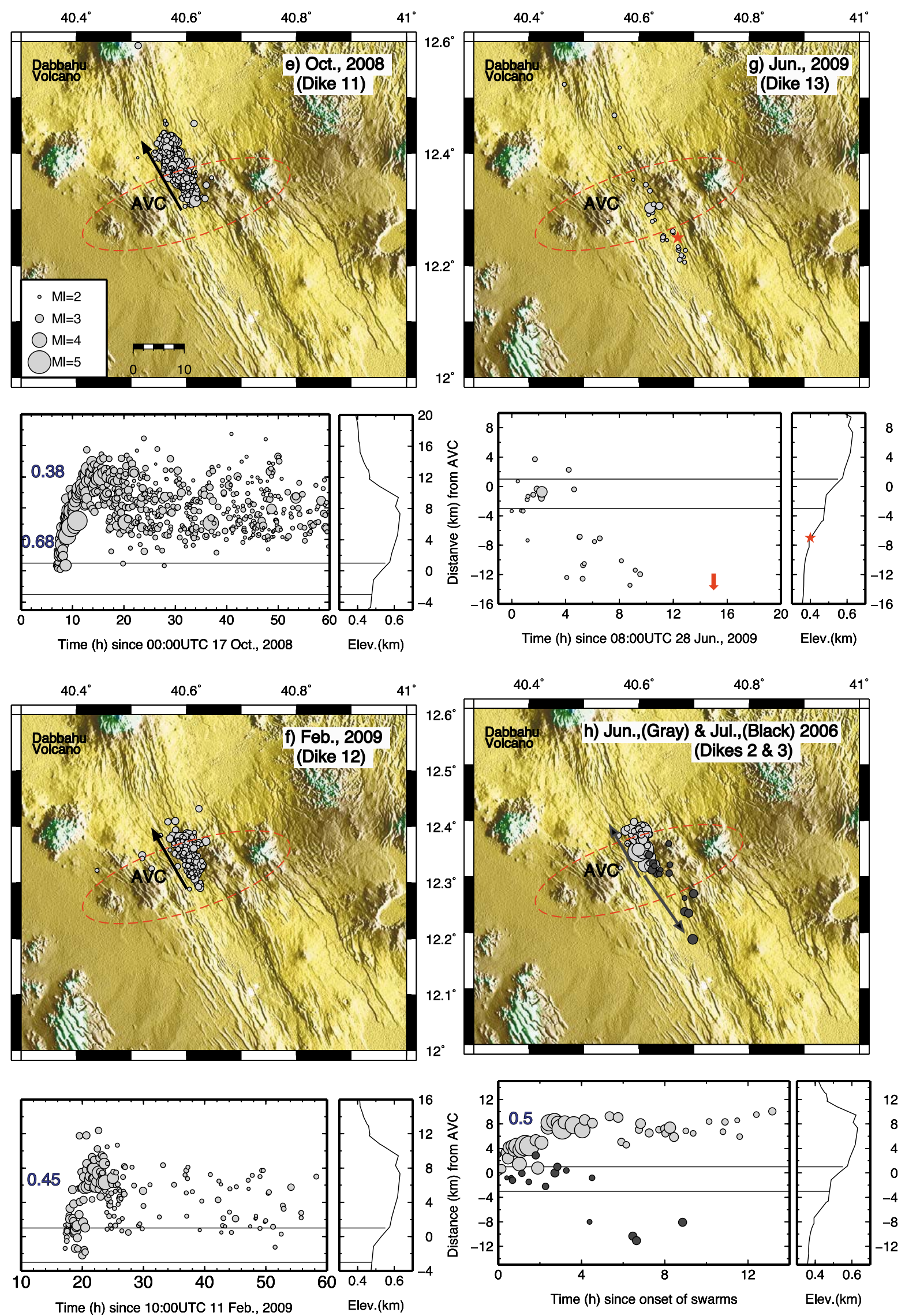

Figure 3. (continued) 
north of the AVC. The swarm of earthquakes appears to have migrated northward, but the migration pattern is less clear than the subsequent dikes without fissural eruptions for which there were a large number of recorded earthquakes (Figures 3a-3f). The northward migrating swarm of earthquakes followed parts of intruded rift portions of Dikes 1,2 and 5, as determined from fault mapping [Rowland et al., 2007], InSAR [Wright et al., 2006; Grandin et al., 2009; Hamling et al., 2009] and seismicity [Ayele et al., 2009; Keir et al., 2009]. A total seismic moment estimate of $1.293 \mathrm{e}+$ $15 \mathrm{Nm}$ is obtained which is $\sim 0.08 \%$ of the estimate determined from geodetic modeling (Table 1).

\subsection{The 11-13 November 2007 Intrusion (Dike 8)}

[20] The first recorded earthquake for this dike intrusion was a tectonic earthquake of $\mathrm{M}_{\mathrm{L}}=2.9$ located $\sim 7 \mathrm{~km}$ south of AVC on 11 November 2007 at 16:04 (Figures $3 b$ and 4b). This swarm of $<3 \mathrm{M}_{\mathrm{L}}$ tectonic earthquakes migrated southeast along the rift at a rate of $\sim 0.35 \mathrm{~m} / \mathrm{s}$ for $\sim 4 \mathrm{~h}$ (Figure $3 \mathrm{~b}$ ). The migration continued further south with a decreased rate of $0.23 \mathrm{~m} / \mathrm{s}$ for the following $15 \mathrm{~h}$ (between $\sim 21: 00$ on 11 November and 12:00 on 12 November) after the generation of a magnitude 3.9 low-frequency earthquake at 20:37 (Figure $4 \mathrm{~b}$ ). The time of change in the migration rate is marked by increased rate of seismicity reaching a maximum of 17 events per hour around 20:30 on 11 November followed by an average number of 11 events per hour for $10 \mathrm{~h}$ (Figure 5b). Hypocenters are distributed mainly between the surface and $3 \mathrm{~km}$ with few earthquakes from depths up to $8 \mathrm{~km}$ (Figure 6b). Out of a total of 361 events recorded, 52 were $\mathrm{M}_{\mathrm{L}}>3$ during the six days of continuous seismic activity and 21 were low-frequency events including the largest event, the $\mathrm{M}_{\mathrm{L}}=4.5$ at $21: 21$ on 11 November. On 12 November around 12:00, the seismicity ceased to migrate, although mainly small magnitude $\left(<2.5 \mathrm{M}_{\mathrm{L}}\right)$ earthquakes continued to occur at the end and along the length of the inferred dike (Figure $3 \mathrm{~b}$ ). Nearly $10 \mathrm{~h}$ later, seismicity began to migrate along the eastern side of the rift for another $15 \mathrm{~h}$ at a rate of $0.15 \mathrm{~m} / \mathrm{s}$ and increased to a maximum of 12 events per hour (Figure $5 \mathrm{~b}$ ). This second migrating swarm had fewer (89) earthquakes with magnitudes between 2.3 and 3.7, and no low-frequency events were detected (Figure $4 \mathrm{~b}$ ). No earthquake was recorded from the region intruded by the first discrete dike until the second dike stopped. The southward migration of seismicity stopped around 13:00 on 13 November 2007 followed by $\sim 6$ days of high rates of postdiking seismicity along the entire length intruded by this $\sim 24 \mathrm{~km}$ long dike.

[21] The distribution of earthquakes shows that this dike was intruded as two discrete dikes, with a $10 \mathrm{~h}$ stall period between the two dikes. The total seismic moment is $\sim 1.027 \mathrm{e}+17 \mathrm{Nm}$ which is $\sim 3.3 \%$ of the geodetic moment estimate (Table 1). About $82 \%$ of the energy was released during propagation of the two discrete dikes. Moreover, the first segment of the dike accounts for $\sim 60 \%$ of the seismic energy release during propagation. Important to note is that the geodetic models fail to detect the second, deeper southern dike, and the surface deformation is attributed to the opening along the length of the first dike (Table 1).

\subsection{The 31 March to 1 April 2008 Intrusion (Dike 9)}

[22] A new seismic swarm started $\sim 6 \mathrm{~km}$ south of AVC at 03:38 on 31 March 2010 with a small magnitude earthquake. Another small event $7 \mathrm{~h}$ later was located $\sim 4 \mathrm{~km}$ to the south along the length of the rift axis (Figure 3c). This is followed by diffuse southward migrating seismicity for $\sim 6 \mathrm{~h}$ over $\sim 4 \mathrm{~km}$ along-axis length. After a $\sim 2 \mathrm{~h}$ gap of recorded seismicity, earthquake swarm migration recommenced around 18:54 at a rate of $\sim 0.16 \mathrm{~m} / \mathrm{s}$ until it reached its southern end at $\sim 04: 30$ on 01 April 2008. The seismicity rate increased $16 \mathrm{~h}$ after the onset of the swarm reaching a maximum of 32 events per hour at around 22:30. This elevated rate lasted for $6 \mathrm{~h}$ with an average 18 events per hour between $\sim$ 19:30 on 31 March and 01:30 on 01 April (Figure 5c). Postmigration seismicity continued to occur at the southern end of the swarm for almost 3 days. Only one low-frequency event was recorded toward the northern end of the swarm after the dike stopped propagating (Figure 4c). Unlike the other dikes discussed here, most of the earthquakes associated with Dike 9 are limited to depths between $3 \mathrm{~km}$ and $10 \mathrm{~km}$ (Figure $6 \mathrm{c}$ ). The clustered epicenters extend for $\sim 12 \mathrm{~km}$ along the rift, and then follow the length intruded by the first discrete dike in November 2007. Seismic moment, $\sim 88 \%$ of which is released during the $19 \mathrm{~h}$ of swarm migration, is estimated to be $\sim 1.563 \mathrm{e}+16 \mathrm{Nm}$. This is only $0.4 \%$ of the geodetic moment (Table 1).

\subsection{The 9-10 July 2008 Intrusion (Dike 10)}

[23] Dike 10 intruded the same region south of the midsegment as the previous two dikes (Figure 3d). The earthquake swarm associated with this dike started at $08: 24$ on 9 July 2008 close to the midsegment, and propagated south at a rate of $\sim 0.26 \mathrm{~m} / \mathrm{s}$ until $14: 38$ on 10 July (Figure $3 \mathrm{~d}$ ), taking a total of $30 \mathrm{~h}$ to reach its southern end. During the entire migration period of the earthquake swarm from this dike persistent seismicity was recorded from the rift between Dabbahu Volcano and AVC (Figure 3d). Low-frequency earthquakes occurred a few hours after the onset of the swarm, and earthquakes range in magnitude between 1.8 and $2.5 \mathrm{M}_{\mathrm{L}}$ (Figure $4 \mathrm{~d}$ ). The seismicity rate was relatively low during the first $8 \mathrm{~h}$ since the onset of the swarm, with an average rate of three events per hour (Figure 5d). A sharp increase in the number of earthquakes is observed starting from around 17:30 on 9 July, and high seismicity levels

Figure 3. (a-h) Distribution of dike-induced seismicity superposed on DEM, and their migration patterns along the rift axis. Earthquakes are scaled by magnitude, and the legends in Figures 3a and 3e apply for the other dikes. The lower plots for each dike show along-axis patterns of earthquake migration and the decimal numbers indicate average migration rates. Black arrows show the seismicity migration directions. The horizontal lines represent the positions of the inferred magma feeder zone, and along-rift topographic relief is shown to the right. The red stars in Figures 3a and 3g show the 12 August 2007 and 28 June 2009 fissural eruption locations and the red arrow shows the time at which the first thermal signal was detected by MODIS. The darker dots in Figure 3d represent nonmigrating earthquake swarms that occurred during the July 2008 dike emplacement. 

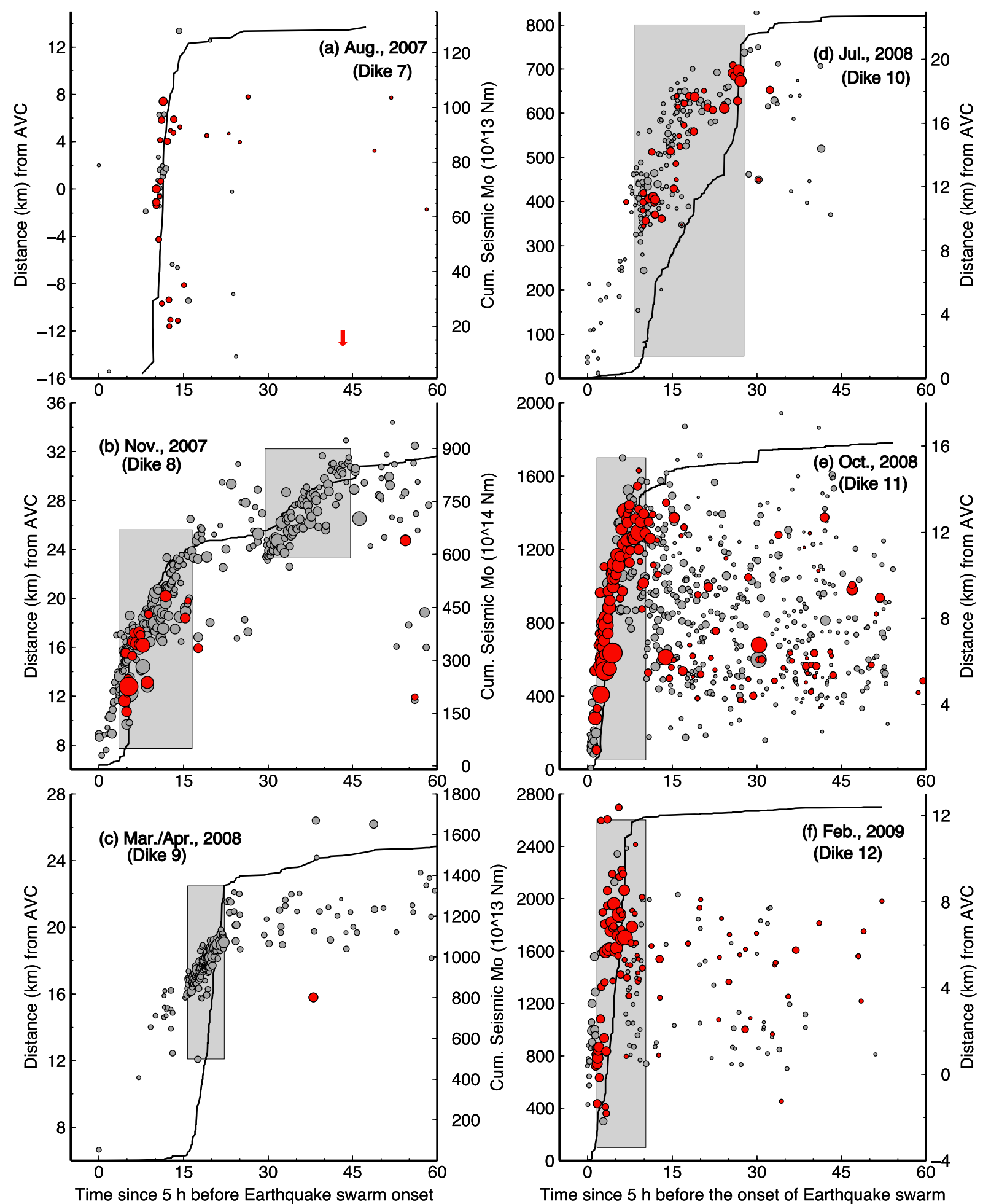

Time since $5 \mathrm{~h}$ before the onset of Earthquake swarm

Figure 4. (a-g) Along-rift distance and cumulative seismic moment versus time in hours commencing $5 \mathrm{~h}$ before the onset of earthquake swarms for dikes since 2007. Stations were too sparsely located to evaluate the frequency content of Dikes 2 and 3 [Keir et al., 2009]. The time axis is the same for all plots. Gray dots are epicenters and red dots are those with peak frequency $\leq 2 \mathrm{~Hz}$, both scaled by magnitude as earlier figures. The vertical red arrows in Figures $4 \mathrm{a}$ and $4 \mathrm{~g}$ show the times of first thermal signal detected by MODIS. (h) Normalized cumulative seismic moment versus normalized time. Normalized moment is the cumulative moment divided by the total estimated seismic moment for each dike, and normalized time is time since the onset of swarm divided by the duration of the swarm. Although high-resolution GPS data were unavailable to this study, the anticipated time window for dike opening and slow slip events is shaded, based on analogy to patterns of Keir et al. [2009] and Hamling [2010]. 


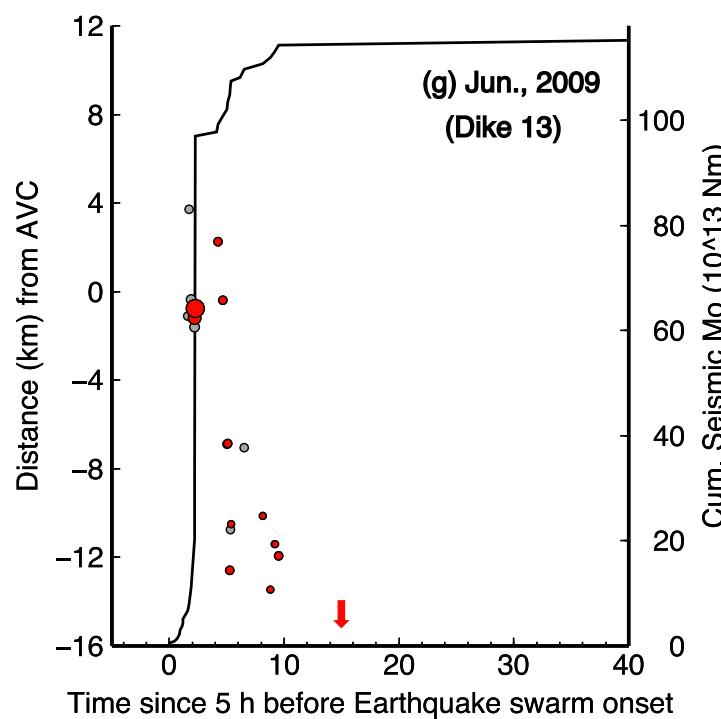

Figure 4. (continued) continued for $9 \mathrm{~h}$ with an average rate of 13 events per hour (Figure 5d). The increased rate of scattered seismicity coincides with the occurrence of low-frequency earthquakes (Figure 5d). The along-axis profile shows the events span depths between $0 \mathrm{~km}$ and $\sim 7 \mathrm{~km}$ (Figure 6d). Few earthquakes were recorded after the swarm migration stopped. The epicenters extend for $\sim 20 \mathrm{~km}$ south along the rift. The total seismic moment is $\sim 8.247 \mathrm{e}+15 \mathrm{Nm}, \sim 0.28 \%$ of geodetic moment (Tables 1 and 2).

\subsection{The 17 October 2008 Intrusion (Dike 11)}

[24] Dikes 8-10 were limited only to the rift portion either close to or south of the AVC. Dike 11 broke this pattern with a northward migrating seismic swarm that began at approximately $07: 15$ on October 17,2008 close to AVC with a small magnitude tectonic earthquake. The swarm migrated the first $6 \mathrm{~km}$ at $\sim 0.68 \mathrm{~m} / \mathrm{s}$, then slowed to $\sim 0.38 \mathrm{~m} / \mathrm{s}$ until it stopped around 15:00 (Figure 3e). At 07:55 on 17 October the first low-frequency earthquake was recorded when the migration started to slow down. These lowfrequency events are distributed along the entire $15 \mathrm{~km}$ length of the dike, and they continued to occur after the migration stopped (Figure $4 \mathrm{e}$ ). During the $\sim 8 \mathrm{~h}$ of dike propagation an average of 14 events per hour were recorded (Figure 5e), and this intense activity continued for more than four days after the dike ceased to propagate. The earthquakes have depths that range from the surface to $\sim 8 \mathrm{~km}$ subsurface (Figure 6e). Out of the over 600 earthquakes recorded during this intrusion 100 (75 during the $8 \mathrm{~h}$ migration period) of them were of magnitude $\geq 3$ with the maximum being a $4.6 \mathrm{M}_{\mathrm{L}}$ earthquake. The total seismic moment is $\sim 1.781 \mathrm{e}+17 \mathrm{Nm}$ which is $\sim 2.26 \%$ of the geodetic moment (Tables 1 and 2). About $77 \%$ of the seismic energy was released during the dike propagation phase.

\subsection{The 11-12 February 2009 Intrusion (Dike 12)}

[25] Dike 12 began with a small magnitude earthquake $\left(\mathrm{M}_{\mathrm{L}}=2\right)$ at 17:11 on 11 February $2009 \sim 2 \mathrm{~km}$ south of the onset location of the earthquake swarm for the October 2008 (Dike 11) dike intrusion. Scattered swarms of earthquakes progressively migrated north along the rift at an average rate of $\sim 0.48 \mathrm{~m} / \mathrm{s}$ (Figure 3f). Low-frequency earthquakes commenced an hour after the onset of the swarm (Figure 4f). The seismicity reached its northern end in $\sim 7 \mathrm{~h}$, and it marks an approximately $12 \mathrm{~km}$ along-axis distance (Figure 3f). High levels of seismicity, however, continued for $\sim 10 \mathrm{~h}$ with an average of 12 events per hour (Figure $5 \mathrm{f}$ ), and earthquakes have depths of $0-8 \mathrm{~km}$ (Figure $6 \mathrm{f}$ ). The inferred dike followed the same rift path as Dike 11 but was shorter, and had smaller total seismic moment of $\sim 2.701 \mathrm{e}+16 \mathrm{Nm}(\sim 0.89 \%$ of geodetic moment) (Tables 1 and 2). Of the 185 events, 30 earthquakes with $\mathrm{M}_{\mathrm{L}} \geq 3$ were recorded during the migration phase of the swarm. Postdiking seismicity continued for 2 days with smaller magnitude $\left(<2 \mathrm{M}_{\mathrm{L}}\right)$ earthquakes.

\subsection{The June 2009 Fissural Eruption (Dike 13)}

[26] On 28 June 2009 MODIS reported the first thermal alert at 23:20 from the same location as the August 2007 fissural eruption (Figures $3 \mathrm{~g}$ and $4 \mathrm{~g}$ ). The eruption was preceded by a seismic swarm that started around 08:00 on 28 June 2009, located close to the AVC. Low-frequency earthquakes started two hours after the first located event (Figure $4 \mathrm{~g}$ ). The pattern of sparse seismicity shows that the dike propagated south along the rift reaching the surface at the site of the August basaltic fissural eruption [Ferguson et al., 2010] (Figures 3a and 3b). Only 33 locatable earthquakes with magnitudes between 2 and 3 were recorded by the network giving a total seismic moment of $1.178 \mathrm{e}+15 \mathrm{Nm}$ $(0.065 \%$ of geodetic moment estimate) (Tables 1 and 2$)$. As in the August 2007 fissural eruption, the June 2009 dike intrusion was largely aseismic.

[27] A field team reached the eruption site on July 4 and found a'a basalt flows approximately 2-3 $\mathrm{m}$ thick sourced from fissures approximately $4-5 \mathrm{~km}$ long, lined by scoria ramparts 30-50 m high [Ferguson et al., 2010]. They estimated the areal coverage of the lava flow $\left(\sim 4.5 \mathrm{~km}^{2}\right)$ from 

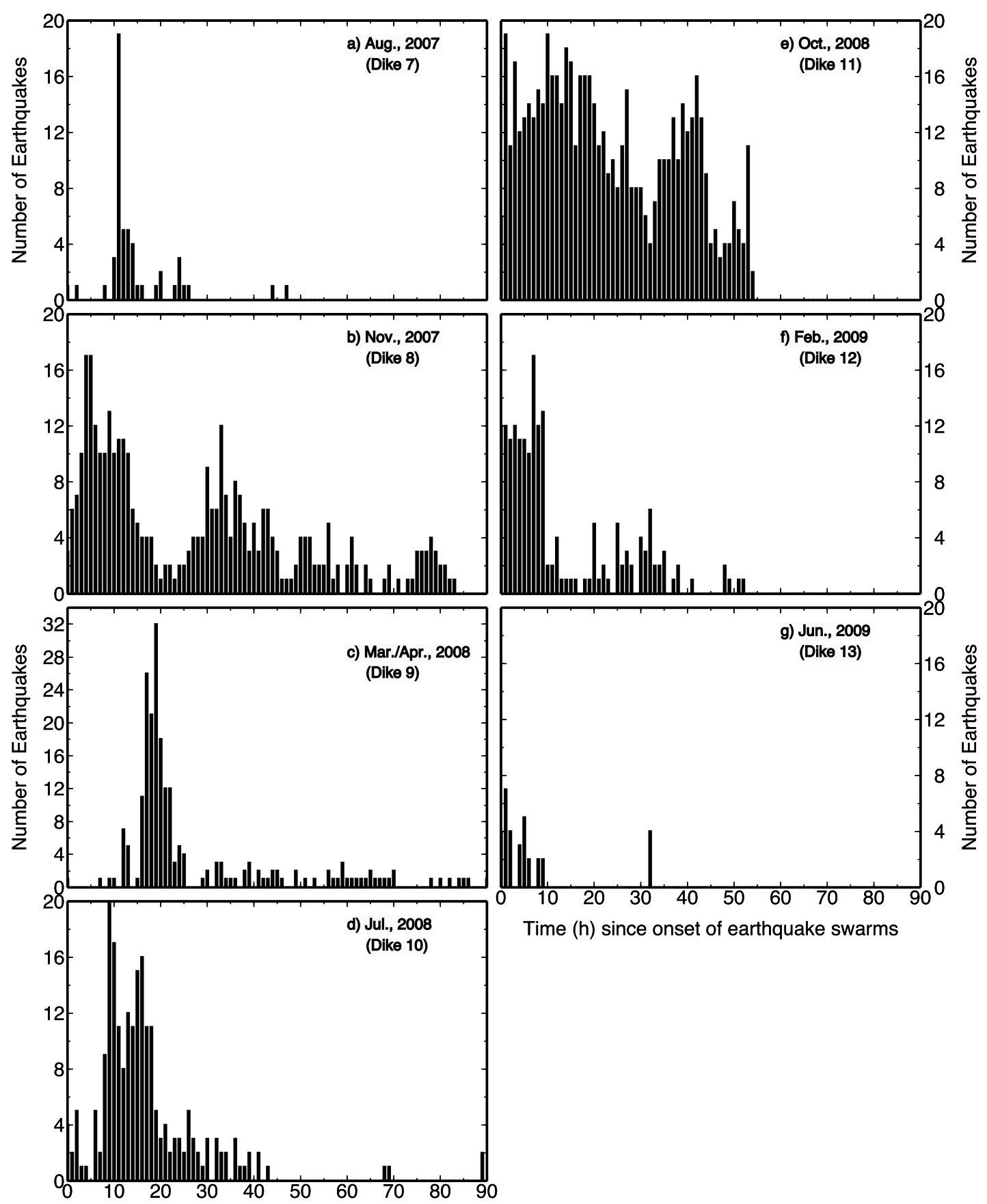

Time (h) since onset of earthquake swarms

Figure 5. Number of earthquakes per hour since the onset of the dike-induced seismic swarms. Although both Dikes 8 and 11 show two distinct peaks, only Dike 8 has two discrete dike propagation events. The second peak in Dike 11 corresponds to an increase in seismicity after the generation of two large magnitude low-frequency earthquakes, but without migrating swarms.

ASTER thermal data and an erupted volume of 0.0135 $0.018 \mathrm{~km}^{3}$. Erupted lavas covered the August 2007 flows and have the same compositions [Ferguson et al., 2010].

\section{Summary}

[28] This comparison of seismicity patterns from Dikes 7 13 and two of three fissural eruptions that took place between 2007 and 2009 reveals several consistent patterns, as well as some distinct differences (Tables 1 and 2). All of the seismicity associated with the dike intrusions and fissural eruptions initiate from an $\sim 5 \mathrm{~km}$ wide elliptical zone within the central rift, just south of the ridge marking the AVC. Depth control is inadequate to distinguish any vertical migration of seismicity. Migrating swarms for each dike followed the same rift path as the preceding intrusions that propagated in the same direction. The northward migrating swarms travel nearly twice as fast as southward migrating 


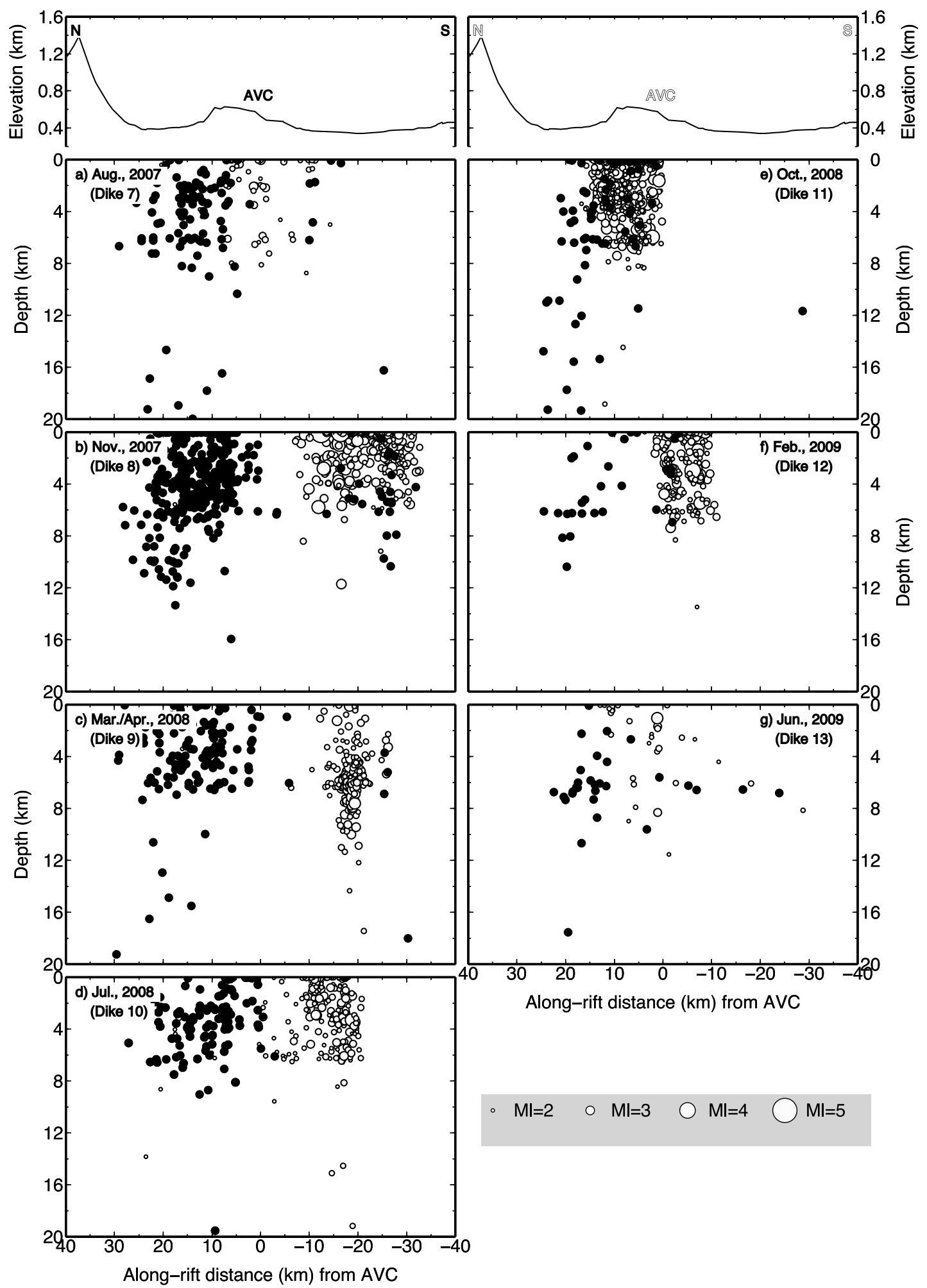

Figure 6. Along-axis depth profiles for Dikes 7-13. Gray circles are earthquakes associated with dike emplacement scaled by magnitude. The black dots are seismicity occurring in the interdike periods. The top graphs on each column show the along-rift topographic profile. Note the persistent swarms of activity between 5 and $20 \mathrm{~km}$ north of the AVC during the period of southward propagating dikes, and the decrease in activity after the large volume October 2008 (Dike 11) intrusion. The profiles run from north $(\mathrm{N})$ to south $(\mathrm{S})$. 


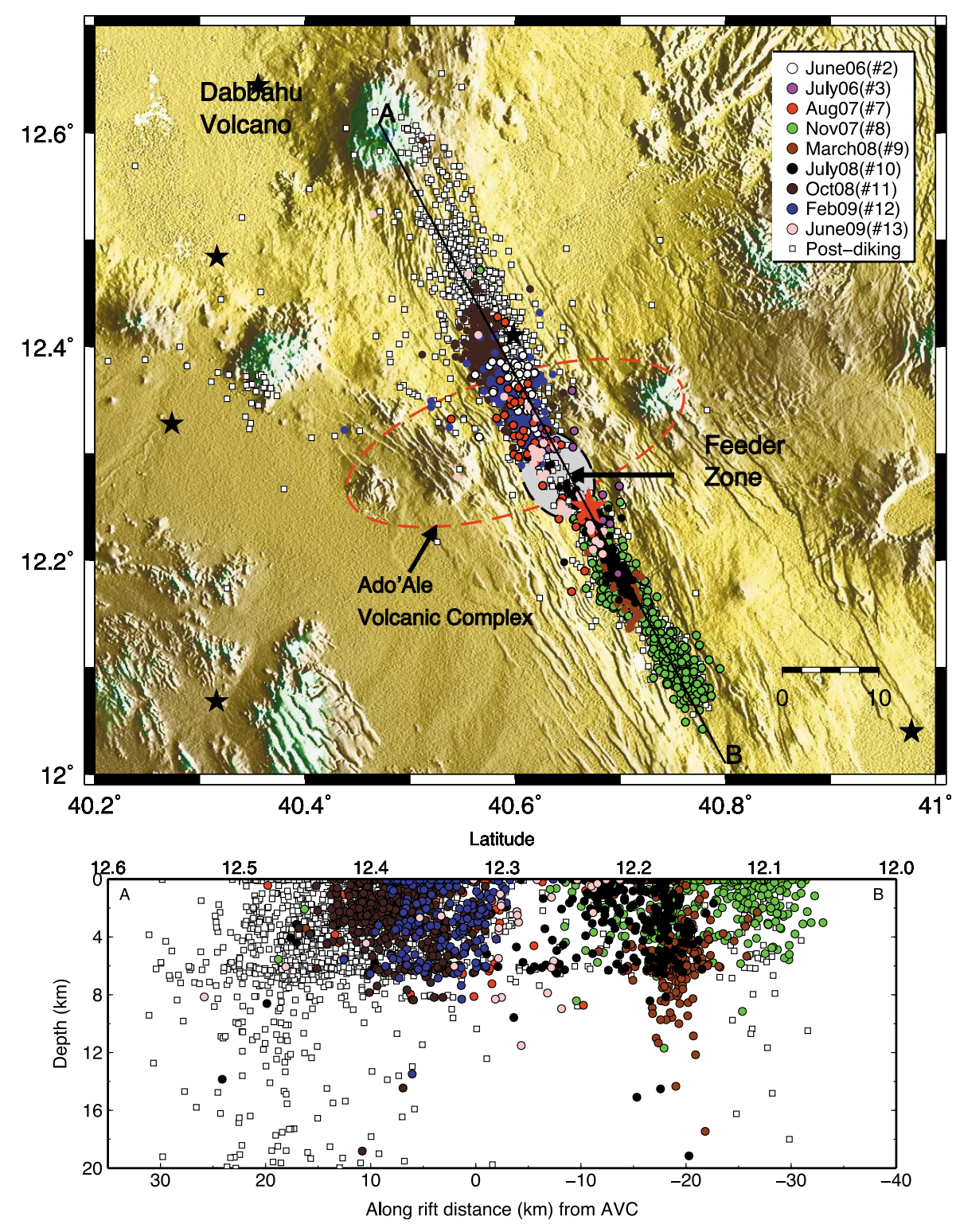

Figure 7. (top) Distribution of epicenters for Dikes 7-13, and Dikes 2 and 3 from Keir et al. [2009] shown on digital elevation model (DEM) of the Dabbahu-Manda Hararo magmatic segment. The distribution of interdike seismicity is shown by white filled squares, excluding the interval between Dikes 1 and 2 [see Ebinger et al., 2008]. The gray shaded area is the largely aseismic zone which marks the onset locations of seismicity for dikes 2, 3 and 7-13. The red star shows the August 2007 and June 2009 fissural eruption site. The black stars are seismic stations. The red ellipse bounds the Ado'Ale Volcanic complex. (bottom) Along-rift profile (A-B) showing the depth distribution of both dike-induced and postdiking seismicity color coded as the top figure. The slight clustering at $6 \mathrm{~km}$ could be an artifact of the discontinuity in the minimum 1D velocity model used to locate the earthquakes (see Figure S2).

swarms. In addition, seismicity patterns are characterized by low-frequency earthquakes that occurred hours after the onset of migrating seismicity, and these unusual earthquakes are distributed along the entire intrusion lengths for all but the second, deeper segment of Dike 8, and for all of Dike 9. The cumulative seismic moment curves for all the dikes have a typical 'long s' shape (Figure 4) with a minimal moment release after the dike stopped propagating. In addition, $>80 \%$ of seismic energy is released during propagation of the dikes (Table 2). The dikes with fissural eruptions were relatively aseismic and the majority of the earthquakes are low-frequency earthquakes. The interdike seismicity reveals no premonitory activity in the site of the next dike, but instead shows persistent seismicity 5-20 km north of the AVC (Figures 6 and 7).

\section{Discussion}

[29] Current models and observations of laterally propagating dikes in rifts show that seismicity occurs due to increased pore pressure at the dike tip and faulting above and in front of laterally propagating dike due to slip on 
faults that extend into the dike plane [e.g., Einarsson and Brandsdóttir, 1980; Klein et al., 1987; Rubin and Pollard, 1988; Rubin, 1992]. The normalized combined seismicity rate plot (Figure S4) shows a rate stationary pattern as observed for multiple intrusions from Piton de la Fournaise, Mt. Etna and Miyakejima [Traversa and Grasso, 2009]. This suggests the earthquakes during intrusions are triggered by emplacement of magma. The epicenter migration, therefore, serves as a proxy for the lateral propagation of the dikes, and the spatial and temporal distributions and spectral content of the earthquakes are used to describe the timing and dynamics of dike intrusion processes in the DMH rift segment. As we discuss below, the wealth of information from the DMH dike sequences provides additional constraints on the feeder zone(s) for the dike intrusions, implications of dike length patterns and possible controlling factors, dike propagation rates and brittle failure mechanisms along the margins of dikes.

\subsection{Earthquake Distribution}

[30] The dike intrusions in the DMH rift generated migrating swarms of earthquakes that covered along-axis distances that range from 12 to $24 \mathrm{~km}$ (Table 2). The breadths of the seismogenic zones are $<5 \mathrm{~km}$, much broader than the 1-3 m wide dikes themselves taking into consideration the overall $\sim 1 \mathrm{~km}$ horizontal location uncertainties. This is consistent with the areal overlap between seismicity distribution and field observations of normal fault slip across a $3-5 \mathrm{~km}$ wide zone after the 2005 megadike intrusion [Rowland et al., 2007]. During intrusions seismicity is limited only to the intruded portion of the rift except during intrusion of Dike 10 (Figure 3d). Hypocenters are distributed between the surface and up to $10 \mathrm{~km}$ depth (Figures 6 and 7). The exceptions are the second segment of Dike 7 and Dike 9 for which the earthquakes are distributed between $3 \mathrm{~km}$ and $\sim 10 \mathrm{~km}$. The distances covered by migrating earthquake swarms associated with Dikes 7-13 are much longer than the $\sim 10 \mathrm{~km}$ dike lengths estimated from models of interferograms [Hamling et al., 2009] (Tables 1 and 2). This mismatch may be due to the smaller magnitude earthquakes that mark fractures with minor opening ahead of a propagating dike [e.g., Rubin and Pollard, 1988]. Moreover, oversimplification of elastic models and/or lack of faulting above the deeper dikes, which intrude densely faulted terrain, may also explain the mismatch.

[31] After migration ceases earthquakes continued to occur for days along the inferred dike length with higher concentrations in the middle and tip of the dikes (Table 2 and Figures 3 and 4). Such patterns are also observed during intrusions in basaltic volcanoes, where they have been interpreted to be the result of the volumetric deformation caused by intrusion of magma into the solid medium [Traversa and Grasso, 2009; Traversa et al., 2010]. Thermal stress may also contribute to high seismicity levels after dike intrusions [Coté et al., 2009]. Unlike the September 2005 megadike intrusion, the Dabbahu volcano region has been aseismic since 2007 consistent with Ayele et al.'s [2009] interpretation that the 2005 swarm close to Dabbahu volcano were distinct from the propagating dikes and may have triggered the subsequent dike intrusions sourced from beneath the AVC.
[32] Dikes 7 and 13 resulted in fissural basaltic eruptions, and they were largely aseismic. The low seismicity rate for these dikes can be attributed to various factors. One possibility is the weak rheology of the rocks above the feeder zone which results in a lower ambient background differential stress. Geodetic estimates show the two dikes are shallower and smaller in volume than the rest of the dikes in the DMH [e.g., Hamling et al., 2009]. These parameters imply that lower stressing rate, which has a direct scaling with dike volume [Pedersen et al., 2007]. Moreover, the eruption to the south of the AVC could be due to the ease to reach the surface than it is to the north where there is loading from topography.

[33] Between dike intrusions earthquakes from the $\mathrm{DMH}$ segment are low, and limited to the rift north of AVC between $12.4^{\circ} \mathrm{N}$ and $12.5^{\circ} \mathrm{N}$ (Figures 6 and 7). This rift portion was aseismic during the intrusion periods, and seismicity peaked after the dike-induced seismicity ceased. Most of the events are distributed between depths of $4 \mathrm{~km}$ and $9 \mathrm{~km}$ with a few events at shallower depths and depths greater than $10 \mathrm{~km}$. The epicenters of these events coincide with the region where maximum geodetic opening was measured following the intrusion of the September 2005 dike [Wright et al., 2006; Grandin et al., 2009]. Grandin et al. [2010b] interpreted the interdiking surface deformation detected from InSAR as the result of magma ascent into a shallow crustal feeder zone in the midsegment. Therefore, the timing of occurrence of the high level seismicity relative to the dike intrusion periods may show the presence of lower crustal magma source(s) possibly connected with the shallower midsegment feeder zone.

\subsection{Location of Feeder Zone}

[34] The relatively high quality seismic data used in this study allows us to compare the onset locations of the migrating swarms for each dike. All of the dikes initiate from a $<5 \mathrm{~km}$ radius zone centered just south of the Ado'Ale Volcanic Complex $\left(12.28^{\circ} \mathrm{N}\right.$ and $40.64^{\circ} \mathrm{E}$, Figures 7 and 8$)$. Earthquake swarms migrated to the north or south from the center of the rift segment, and the two and half year seismicity distribution reveals a seismicity gap in the inferred feeder zone (Figures 7 and 8), consistent with the possible presence of a hot, fluid-rich, and weak region that extends to near the surface. Uncertainties in depth estimates for the commonly small magnitude earthquakes at the onset of dike propagation prevent a clear image of the shape of the magma feeder zone(s). Assuming that the dikes initiate along zones of high fluid pressure along the margins of a magma chamber, the $\sim 5 \mathrm{~km}$ radius of dike onset locations suggests the midsegment weak zone is underlain by a large a midcrustal magma chamber with approximate along-axis dimension of $<5 \mathrm{~km}$. Our results refine the location and dimensions of the magma source zone near the center of the rift segment, and are consistent with the results of earlier seismic and geodetic studies [Ayele et al., 2009; Keir et al., 2009; Hamling et al., 2009; Grandin et al., 2010a] (Figures 7,8 , and 9).

[35] Clear S arrivals recorded on stations on either side of the rift, and the absence of a shallow high conductivity zone in 3D models of magnetotelluric data [Hautot et al., 2009] suggest that the magma reservoir feeding the dikes could possibly be deeper than $6 \mathrm{~km}$. If these large volume dikes 

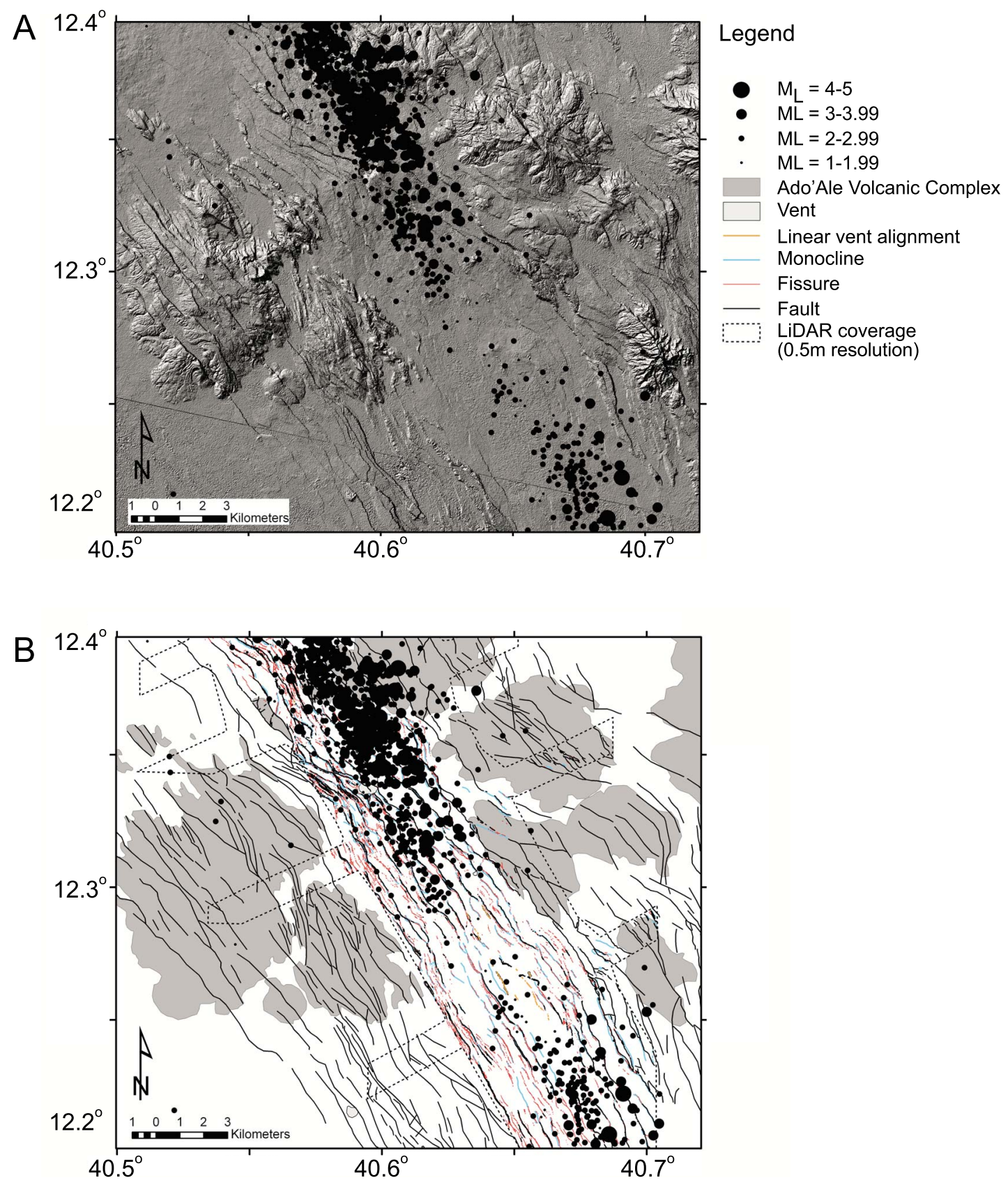

Figure 8. Detailed relations between the inferred magma source zone beneath the center of the DMH rift segment, surface fault patterns, and seismicity. Epicenter distribution from all the dikes around AVC superposed on (a) $6 \mathrm{~m}$ resolution DEM of the Ado'Ale Volcanic Complex constructed from SPOT 5 satellite imagery, provided courtesy of Sophie H and (b) structural map derived from a 0.5 spatial resolution lidar data. The broken lines bound the region for which lidar data is available. The inferred feeder zone shown in Figure 7 is clearly seen here with a gap in seismicity. Earthquakes are scaled to magnitude.

were sourced from a shallow magma reservoir, one would expect to image subsidence patterns in interferograms during intrusions. Yet, only interferograms from Dike 8 (November 2007) and Dike 10 (October 2008) show small lobes of subsidence near the segment center close to AVC [Hamling et al., 2009; Grandin et al., 2010a; Hamling, 2010]. Fault deformation associated with Dike 1 was intense, masking any subsidence signal near the heavily faulted midsegment feeder zone [Wright et al., 2006; Grandin et al.,
2009]. These subsidence fringes may signal a large and rapid pressure drop related to the relatively large volume of magma intruded for the two dikes [Rivalta, 2010] or presence of a shallower chamber that fed the dikes [Hamling et al., 2009; Hamling, 2010]. However, as discussed above, the interdiking seismicity and surface deformation patterns observed suggest a deeper magma chamber beneath AVC [Grandin et al., 2010b], and possibly between Dabbahu volcano and AVC (Figure 9). 

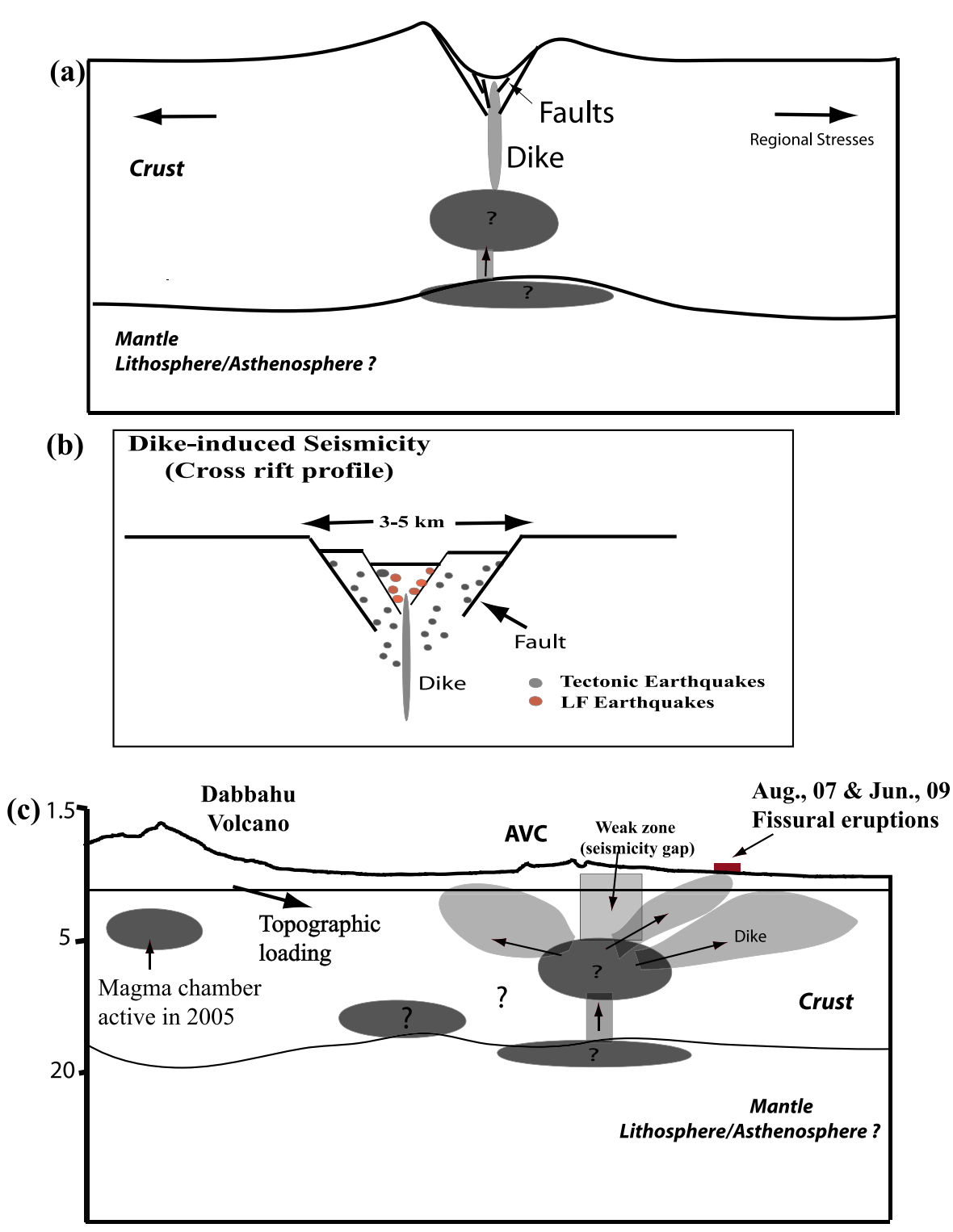

Figure 9. Cartoon model integrating the dike-induced seismicity patterns and geodetic constraints on the probable magma source zones for Dikes 2-13 in the Dabbahu-Manda Hararo rift segment. (a) Across rift profile showing the midcrustal to subcrustal chambers, dikes, and faults activated by the multiple intrusions. (b) Zoomed in cross rift profile showing distribution of low-frequency and tectonic earthquakes, and the $3-5 \mathrm{~km}$ zone of faults with surface offsets of up to $3 \mathrm{~m}$. Red dots indicate low-frequency earthquakes that are generated by the interaction between graben forming faults and the dikes. The black dots represent distributions of tectonic earthquakes. (c) Along-axis topography relative to the dikes, subcrustal magma chambers, and possible upper mantle reservoir(s). The deep crustal magma reservoir beneath the northern part of the midsegment is inferred from the persistent and deeper earthquake swarms between dike intrusions.

\subsection{Dike Lengths and Stress 'Barriers'}

[36] The distance a dike propagates along a rift is controlled mainly by the level of magma chamber pressure, tectonic stress, the rate of pressure drop due to magma withdrawal, viscous resistance to flow, presence of regions of higher relative tectonic compression, stress barriers and loading from topography [Delaney and Pollard, 1982; Rubin, 1995; Behn et al., 2006; Buck et al., 2006, Rivalta and Segall, 2008]. Various models and observations of dike intrusion processes show that dike opening stops when the tip of the down-rift propagating dike stops [e.g., Tryggvason, 1984; Rubin et al., 1998; Rubin and Gillard, 1998; Buck et al., 2006; Rivalta, 2010]. Modeling of the kinematics of blade-like dike intrusions indicate that flexure at the brittleductile boundary due to the development of rift topography inhibits further propagation of dikes along the rift [e.g., Pinel and Jaupart, 2004; Behn et al., 2006]. Stress barriers along the dike path such as transform faults or the presence of en echelon fault systems, pronounced along-axis varia- 


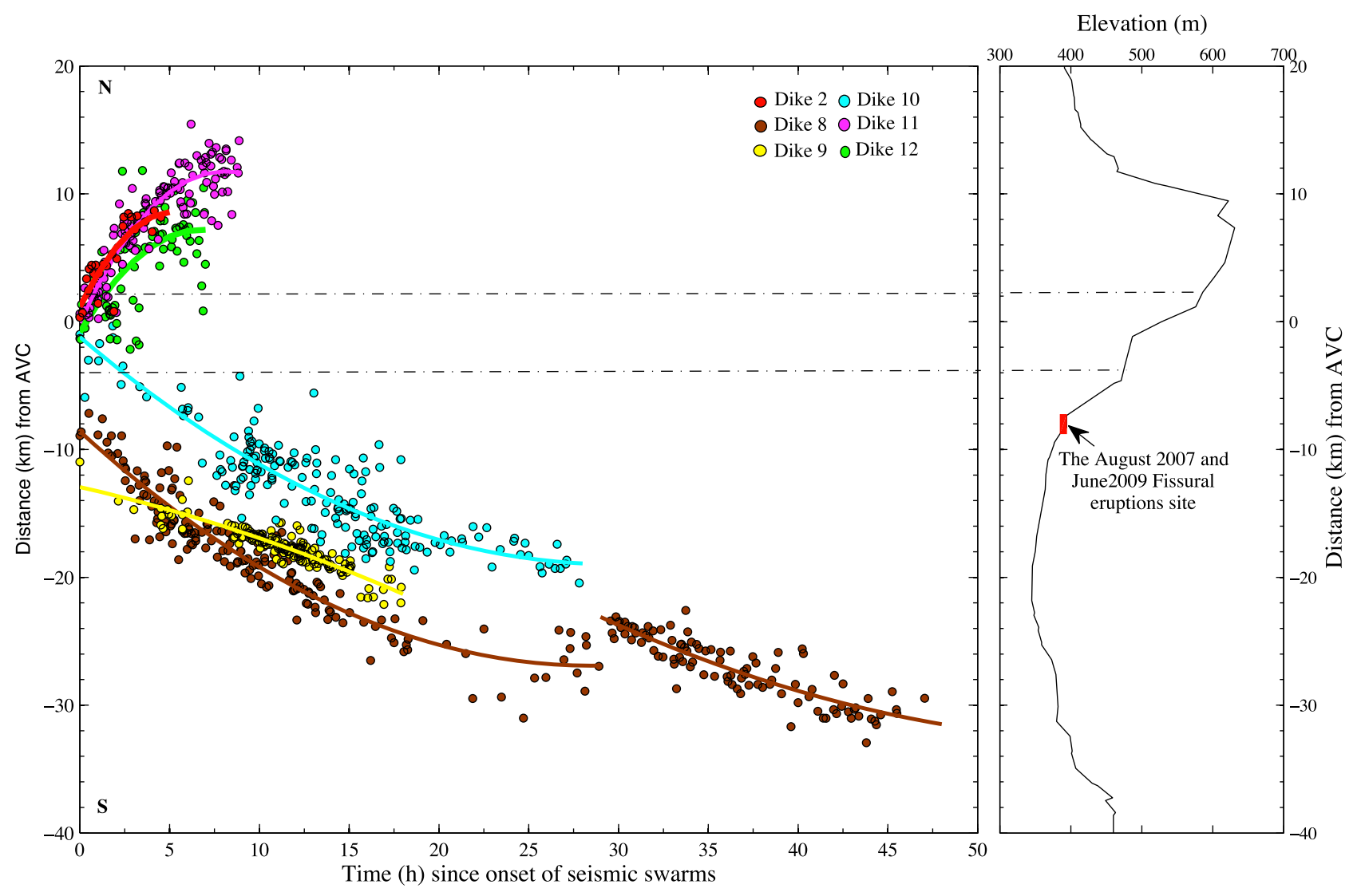

Figure 10. Migration patterns of epicenters for 6 of the dike intrusions presented in this paper. Curve fits show an exponential decrease in migration velocities with increase in dike propagation distance from the midsegment aseismic zone above the interpreted midcrustal to lower crustal magma chamber.

tion in the state of stress and other kinds of 'asperities' may limit the extent of dikes within rift zones [e.g., Einarsson, 1991; Buck et al., 2006].

[37] All of the southward propagating dikes (first part of Dike 8, and Dikes 9 and 10) stopped at nearly the same location (Figure 10). The absence of any topographic feature south of the AVC suggests an asperity or structural step may have a role in limiting the dike lengths. Northward migrating earthquakes covered shorter along-axis distances $(<15 \mathrm{~km})$, but swarm terminations varied from dike to dike (Table 2). Earthquakes from Dike 11, the largest dike volume, reached $\sim 15 \mathrm{~km}$ north of the AVC (Tables 1 and 2). By analogy to models of Buck et al. [2006] and Behn et al. [2006], the shorter dike lengths in the northern rift sector may be a consequence of the topographic load of Dabbahu volcano, which has a summit elevation of $\sim 1400 \mathrm{~m}$ above sea level and $\sim 10 \mathrm{~km}$ radius, relative to the $\sim 400 \mathrm{~m}$ mean elevation (Figure 9).

[38] Dike intrusions increase the least compressive stress so that subsequent dike intrusions encounter an ambient stress that is far from failure, resulting in shorter dikes [Rubin, 1995; Buck et al., 2006]. A comparison of dike lengths does not show a clear systematic change in the length of the dikes within a sequence, as was estimated from models of geodetic data (Figure 2) (Tables 1 and 2). For instance, among the southward propagating dikes, the two segments of Dike 8 covered $\sim 25 \mathrm{~km}$ along-axis length. The following dike, Dike 9, propagated a distance of $11 \mathrm{~km}$ in the same direction. However, Dike 10, which started propagation closer to AVC than the previous two dikes, intruded $\sim 21 \mathrm{~km}$ along-axis length. The intrusion of only two dikes to the north, 17 October 2008 (Dike 11) and 11-12 February 2009 (Dike 12), so far did not allow us to confirm the pattern in dike length change in another sequence. These observations indicate that factors other than the evolution of tectonic stresses due to preceding intrusions probably influence the pattern of dike length changes. Such variations in dike length could be related to ambient stress level that is close to failure due to previous intrusions [Rubin and Gillard, 1998], or the degree of fracturing in earlier dikes.

[39] The first segment of Dike 8 and Dikes 9 and 10, stopped propagation at nearly the same position; only the second segment of Dike 8 passed this point (Figure 10). The presence of stress 'barriers'/asperities could be a plausible explanation for this southern termination 'point' for the dikes. The segmentation of the November 2007 dike, Dike 8, the $10 \mathrm{~h}$ gap in seismicity migration between the two discrete dikes and the lack of seismicity along the length of the rift portion intruded by the first part, shows the second discrete dike propagated further south after the driving pressure reached a "breakout" pressure during the $10 \mathrm{~h}$ gap.

\subsection{Propagation Rates}

[40] The observed deflation signals and subsidence above magma chambers and laterally migrating seismicity away from the feeder zone indicate movement of magma along 
rifts [e.g., Einarsson and Brandsdóttir, 1980; Rubin et al., 1998; Toda et al., 2002]. However, the rates at which dikes propagate are difficult to measure, and are estimated based on indirect observations. Migration rates of epicenters and analysis of waveforms [e.g., Moore and Krivoy, 1964; Brandsdóttir and Einarsson, 1979; Einarsson and Brandsdóttir, 1980; Okamura et al., 1988], and geodetic data were used to determine the velocities of dike propagation [e.g., Björnsson et al., 1979; Toutain et al., 1992]. In addition, the size and composition of xenoliths carried by the flow have also been used to determine estimates of the rates of transportation [Carmichael et al., 1977; Spera, 1980; Pasteris, 1984]. These observations at different rift settings show that the migration velocity of seismicity is consistent with dike propagation velocity [Aki et al., 1977; Lister and Kerr, 1991; Battaglia and Aki, 2003], enabling us to use the seismicity migration rates as a proxy for dike propagation.

[41] Dikes that propagated north show higher average migration rates $(0.53 \mathrm{~m} / \mathrm{s}$ for October 2008 and $0.45 \mathrm{~m} / \mathrm{s}$ for February 2009] than the ones that propagated south (November $2007-0.24 \mathrm{~m} / \mathrm{s}$, March/April $2008-0.16 \mathrm{~m} / \mathrm{s}$ and July $2008-0.26 \mathrm{~m} / \mathrm{s}$ ) (Figure 10). In addition, the durations of swarm migrations are shorter to the north than south (Table 2). The intrusion of the September 2005 megadike and subsequent smaller dikes north of AVC resulted in maximum cumulative opening in the vicinity of the feeder zone [Grandin et al., 2009; Hamling et al., 2009; Ebinger et al., 2010]. The relatively higher rates of propagation to the north of AVC, therefore, could be related to the higher hydraulic connectivity due to the intensive faulting and fracturing between the midsegment feeder zone and the rift portion intruded by the dikes. This ensures a fast pressure drop, resulting in faster propagation and shorter duration [e.g., Rivalta, 2010]. Although small, and excluding the fissural eruptions, a decrease in migration velocity with successive dike intrusions within a sequence of dikes that propagated in one direction is observed (Figure 10).

[42] In addition, for individual dikes the rate decreases exponentially as the dike length increases (Figure 10). Experimental and theoretical considerations of propagation of fluid-filled cracks show a wide range of factors control the velocity of dike propagation. Lister and Kerr [1991] in their model showed for a sufficient amount of fluid injected, resistance to fracture of the host rock and propagation of fluid through preexisting fractures has less effect on the rate of propagation. Instead, the viscous resistance to the flow of magma into the dike tip due to freezing slows down the rate with increase in dike length [Delaney and Pollard, 1982; Lister and Kerr, 1991; Rubin, 1995]. Recent studies, on the other hand, show that the time history of the pressure drop in the magma chamber may be considered to be the most important factor. Pressure in the magma chamber is considered to decrease with time as the dike length increases [e.g., Tryggvason, 1980; Ida, 1999; Buck et al., 2006; Rivalta, 2010]. Models of the coupling between the feeding zone and the dike, and comparisons of studies of the volume history of dikes and feeder chambers show the exponential decrease in the dike propagation rates are mainly due to an exponential pressure drop in the chamber [Segall et al., 2001; Rivalta and Segall, 2008; Rivalta, 2010]. The decrease in the rate of propagation for the individual dikes considered in this paper could be explained in the same way due to the pressure drop in the magma chamber as more magma is fed into the rift and propagates along the rift away from AVC. These patterns also suggest replenishment of the midcrustal magma chamber during the interdike periods increasing the chamber pressure. A higher rate of decay of the migration velocities is observed for the northward propagating dikes (Figure 10) which may be related to the topographic loading from the Dabbahu volcano.

\subsection{Seismic Moment}

[43] In magma-rich oceanic rifts magma intrusion accommodates large proportions of strain [e.g., Buck et al., 2005; Dunn et al., 2005]. A comparison of the total geodetic and seismic moment for the dike intrusions in the $\mathrm{DMH}$ rift segment since 2005 reveals that the seismic moment release is $<3 \%$ of the total geodetic moment, indicating that most of the plate boundary deformation due to intrusion of dikes occurs aseismically. The 'long $\mathrm{S}$ ' shape of the cumulative seismic moment curves for all the dikes shows $>80 \%$ of seismic energy is released during the propagation phase of the dikes (Figure 4) (Table 2). The combined cumulative seismic moment plot shows northward propagating dikes released relatively larger seismic energy compared to the ones that propagated to the south (Figure 4h). The exception is Dike 8 which has a relatively large volume comparable to the northward propagated Dikes 2 and 11 (Table 1). This pattern suggests that dike volume and regions with dense faults close to failure contribute significantly to the seismic energy release.

[44] The earthquake generation mechanisms associated with dike intrusions and the spatiotemporal distribution of the dike-induced earthquakes relative to the propagating dike are not well known. However, subsidence above the dike feeder zone, faulting ahead of the propagating dike, as well as above the dike once emplaced account for the large number of earthquakes recorded during the early phases of dike intrusions [e.g., Okamura et al., 1988; Rubin and Pollard, 1988; Rubin and Gillard, 1998; Rubin et al., 1998]. In Kilauea's East Rift Zone, for example, the temporal distributions of shallow and small magnitude earthquakes and continuous ground tilt changes recorded by tiltmeters close to the rift were used to estimate the probable positions over time of the leading edge of the dike [Okamura et al., 1988; Rubin et al., 1998]. During the 1983 Kilauea intrusion deflation at the summit volcano was measured 90 min after the onset of the seismic swarm [Okamura et al., 1988; Rubin et al., 1998]. Combined seismic and tilt data from a dike intrusion at Mount Etna showed ground tilt was measured at nearby stations after the onset of a swarm of earthquakes [Aloisi et al., 2006]. A similar coincidence in space and time was observed between time-averaged continuous GPS and seismicity for Dikes 2 and 3 in the DMH [Keir et al., 2009].

[45] Field and geodetic observations in various volcanic rifts document graben formation above and ahead of the dike during dike intrusions [e.g., Rubin and Pollard, 1988], but earlier studies of dike intrusions from the $\mathrm{DMH}$ rift segment lack the time resolution, due to poor or lack of seismic network to discriminate between the possible causes of dike-induced migrating seismicity [e.g., Ayele et al., 2009; Keir et al., 2009]. The dikes considered in this paper, except the ones with fissural eruptions, show a clear 
earthquake swarm migration pattern that starts with relatively smaller magnitude tectonic earthquakes that span the first few hours (1-2 h) (Figure 4). These tectonic events are followed by an increase in the magnitude of earthquakes and the onset of low-frequency earthquakes (Figure 4). The majority of the low-frequency (peak frequency $\leq 2 \mathrm{~Hz}$ ) events, which are considered to be related to hydrofracture propagation, resonance of fluid-filled cracks, internal pressure changes due to high impedance contrast resulting from bubbles in the fluid or dynamic interaction between faults and dikes [e.g., Rubin, 1995; Chouet and Julian, 1985, Chouet et al., 1994], have magnitudes $\geq 3$. The anomalously low-frequency content is not wholly a path effect, since tectonic earthquakes occur at the same locations.

[46] The observed time sequence of low-frequency earthquakes compared to the tectonic events gives support to the idea that intrusion processes start with small magnitude tectonic earthquakes mainly from the dike tip in the absence of subsidence above the feeder zone. The delayed onset of low-frequency events and increased level and size of seismicity shows that dike opening due to magma emplacement into fractures and subsequent interactions between faults and dike takes place after the passage of the dike tip. Lowfrequency earthquakes are common except for the southern deeper segment of Dike 8 (Figure 4b), and Dike 9 from which only one low-frequency event was recorded (Figure $4 c$ ). Since dike opening occurs during the migration phase of seismicity, and it stops when the dike tip ceases to propagate [e.g., Rubin, 1995; Okamura et al., 1988; Aloisi et al., 2006], we correlate the low frequency earthquakes with dike opening (Figure 4). Moreover, the seismic moment release patterns suggest that the graben bounding faults in the brittle ligament of rock above the dike form after the passage of the dike tip, and slip coincides with the low-frequency earthquakes. For Dikes 11 and 12 which propagated to the north, low-frequency earthquakes occur for up to 3 days after the swarm ceased to migrate (Figures $4 \mathrm{e}$ and $4 \mathrm{f}$ ), suggesting multiple episodes of fault slip, consistent with the unusually large displacements (3-5m) observed along fault scarps north of the AVC after the passage of the Dikes 1 and 3 [e.g., Wright et al., 2006; Ayele et al., 2007a; Rowland et al., 2007; Keir et al., 2009].

\subsection{Intrusion Intervals}

[47] The frequency of dike intrusion episodes varies from one rift to another and with time within a rift. Notable examples of rifting by a single, intense diking sequence are the Asal rifting episode in 1978 [Abdallah et al., 1979; Cattin et al., 2005], the 1983 Kilauea intrusion [e.g., Okamura et al., 1988], the $2000 \mathrm{Izu}$, Japan intrusion episode [e.g., Toda et al., 2002] and dike intrusions along the mid-Atlantic ridge [e.g., Dziak et al., 1995, 2009] and East Pacific rise [e.g., Tolstoy et al., 2006]. On the other hand, the 1975-1984 Krafla, Iceland sequence is a typical example of extended period of rifting by multiple intrusions of dikes [e.g., Björnsson et al., 1979; Tryggvason, 1984; Einarsson, 1991]. Most of these rifting episodes are preceded by inflation of the feeder zone followed by simultaneous deflation signals and lateral propagation of dikes. These observations and modeling of dike intrusion processes show that the change in the magma pressure within crustal chambers is the main controlling factor together with the local and far-field tectonic stresses [e.g., Tryggvason, 1984, Buck et al., 2006; Rivalta and Segall, 2008; Rivalta, 2010]. Inflow of magma into shallow magma chambers from midcrustal to subcrustal sources is used to explain the increase in the chamber pressure [Björnsson et al., 1979; Tryggvason, 1984; Decker, 1966; Fiske and Kinoshita, 1969; Kinoshita et al., 1974].

[48] Since the onset of the current rifting cycle, dikes in the $\mathrm{DMH}$ rift were intruded at intervals ranging from one month to 8 months, with a slight increase in the time interval between dikes after the August 2007 fissural eruption (Figure 2). However, there is no consistent pattern of change in the time interval within a sequence of dikes that propagated in the same direction and with the volume of the dikes. An exception is the $\sim 9$ month interval after the 2005 megadike which could be related to the relatively large volume of magma intruded [e.g., Wright et al., 2006; Grandin et al., 2009]. The change in the state of stress in rifts due to preceding intrusions and the rate at which the feeder zone pressure is increased by the influx of magma from deeper sources has been proposed to control intrusion intervals [e.g., Björnsson et al., 1979; Buck et al., 2006]. During individual intrusions, the sharp onset of migrating earthquake swarms with no premonitory activity suggests an abrupt change in the driving pressure of the magma chamber from new additions. This could be related to excess magma pressure in the midsegment magma chamber due to a higher rate of melt influx from deeper magma sources suggesting continued recharge of the reservoir since the onset of the volcanotectonic episode in Afar.

\section{Conclusions}

[49] Analysis of the seismicity patterns of the 7 dike intrusions in the Dabbahu-Manda Hararo rift segment sheds light on the timing and dynamics of the rifting process. The distributions of the dike-induced earthquake swarms for all the dikes show magma was mainly fed from a midsegment magma chamber possibly deeper than $6 \mathrm{~km}$. The spatiotemporal distributions of the swarms and the lack of clear subsidence above the inferred magma chamber during most of the intrusions suggest midcrustal to subcrustal magma chamber (Figure 9). However, the persistent and relatively deeper interdiking seismicity spanning rift portion 5-20 km north of Ado'Ale Volcanic Complex suggests a secondary magma reservoir or feeder system that may be interconnected with the magma chamber beneath AVC. The dikes that propagated north of the midsegment have higher seismicity migration rates and short migration duration times relative to the dikes that propagated south. This is most likely the result of intensive faulting and fracturing north of AVC due to the preceding intrusion of large volume Dikes 1 and 2 .

[50] For each dike a large proportion of seismic energy $(>80 \%)$ is released during the propagation phase of the swarms. Such temporal distribution of energy release, in addition to the timing of low-frequency earthquakes, suggest that faulting above the dikes start after the passage of the leading edge of the dikes, and it continues to occur simultaneous with dike propagation and after it stalled. Dike lengths varied from 10 to $20 \mathrm{~km}$, with no systematic change in dike length over time within a sequence of intrusion that propagated in the same direction. Observations of dike intervals and lack of premigration seismicity indicate the 
feeder zone was recharged from deeper source(s) during the intrusion intervals since the onset of the volcanotectonic episode in 2005.

[51] Acknowledgments. We thank the Institute for Geophysics, Space Sciences and Astronomy, the Ethiopian Federal Government, and the Afar Regional State for invaluable assistance throughout all stages of this project. The NERC Afar Consortium led by Tim Wright provided helicopter support for a temporary seismic station in the central rift. Generous field and logistical contributions from Ellen Campbell, Binyam Beyene, Yelebe Birhanu, Mike Kendall, Graham Stuart, Sophie Hautot, Kathy Whaler, Elias Lewi, and Carolina Pagli are much appreciated. Barbara Hofmann produced the high-resolution digital elevation model constructed from SPOT imagery provided by CNRS support to Sophie Hautot. Seis-UK support from Alex Brisbourne and Anna Horleston and IRIS-Passcal support from Michael Fort and Eliana Arias-Dotson ensured the success of seismic studies. Nate Lindsey, Alex Aronovitz, Carolyn VanAlstyne, Megan O'Connor, and Clyde Brown assisted with seismic data analyses. We also would like to thank Roger Buck, Trish Gregg, Scott Nooner, Allan Rubin, and Carolina Pagli for advice and feedback during analyses. We thank the Editor, the Associate Editor, Páll Einarsson, and an anonymous reviewer for their comments that improved the manuscript. The support of National Science Foundation grant EAR-0635789; NERC grants NE/ D008611/1, NE/D01039X/1, NE/E007414/1, and NE/E013945/1 (D.K.); and Marsden Fund grant (J.R.) are gratefully acknowledged. Most of the figures are generated using the GMT software [Wessel and Smith, 1998].

\section{References}

Abdallah, A., V. Courtillot, M. Kasser, A. Y. Le Dain, J. C. Lepine, B. Robineau, J. C. Ruegg, P. Tapponnier, and A. Tarantola (1979), Relevance of Afar seismicity and volcanism to the mechanics of accreting plate boundaries, Nature, 282, 17-23, doi:10.1038/282017a0.

Aki, K. (1965), Maximum likelihood estimate of $b$ in the formula $\log \mathrm{N}=$ a-bM and its confidence limits, Bull. Earthquake Res. Inst. Univ. Tokyo, 237-239.

Aki, K., M. Fehler, and S. Des (1977), Source mechanism of volcanic tremor: Fluid-driven crack models and their application to the 1963 Kilauea eruption, J. Volcanol. Geotherm., Res., 2, 259-287, doi:10.1016/ 0377-0273(77)90003-8.

Aloisi, M., A. Bonaccorso, and S. Gambino (2006), Imaging composite dike propagation (Etna, 2002 case), J. Geophys. Res., 111, B06404, doi:10.1029/2005JB003908.

ArRajehi, A., et al. (2010), Geodetic constraints on present-day motion of the Arabian Plate: Implications for Red Sea and Gulf of Aden rifting, Tectonics, 29, TC3011, doi:10.1029/2009TC002482.

Ayele, A., E. Jacques, M. Kassim, T. Kidane, A. Omar, S. Tait, A. Nercessian, J.-B. Chabalier, and G. King (2007a), The volcano-seismic crisis in Afar, Ethiopia, starting September 2005, Earth Planet. Sci. Lett., 255, 177-187, doi:10.1016/j.epsl.2006.12.014.

Ayele, A., G. Stuart, I. Bastow, and D. Keir (2007b), The August 2002 earthquake sequence in north Afar: Insights into the neotectonics of the Danakil microplate, J. Afr. Earth Sci., 48(2-3), 70-79, doi:10.1016/ j.jafrearsci.2006.06.011.

Ayele, A., D. Keir, C. Ebinger, T. J. Wright, G. W. Stuart, W. R. Buck, E. Jacques, G. Ogubazghi, and J. Sholan (2009), September 2005 megadike emplacement in the Manda- Harraro nascent oceanic rift (Afar depression), Geophys. Res. Lett., 36, L20306, doi:10.1029/ 2009GL039605.

Barberi, F., and J. Varet (1977), Volcanism of Afar: Small-scale plate tectonics implication, Geol. Soc. Am. Bull., 88, 1251-1266, doi:10.1130/ 0016-7606(1977) 88<1251:VOASPT>2.0.CO;2.

Barberi, F., E. Bonnati, G. Marinelli, and J. Varet (1974), Transverse tectonics during the split of continent: Data from the Afar rift, Tectonophysics, 23, 17-29, doi:10.1016/0040-1951(74)90108-5.

Battaglia, J., and K. Aki (2003), Location of seismic events and eruptive fissures on the Piton de la Fournaise volcano using seismic amplitudes, J. Geophys. Res., 108(B8), 2364, doi:10.1029/2002JB002193.

Behn, M., W. R. Buck, and S. Sacks (2006), Topographic controls on dike injection in volcanic rift zones, Earth Planet. Sci. Lett., 246, 188-196, doi:10.1016/j.epsl.2006.04.005.

Bellahsen, N., C. Faccenna, F. Funiciello, J. M. Daniel, and L. Jolivet (2003), Why did Arabia separate from Africa?, Earth Planet. Sci. Lett., 216, 365-381, doi:10.1016/S0012-821X(03)00516-8

Berckhemer, H., B. Baier, H. Bartelsen, A. Behle, H. Burckhardt, H. Gebrande, J. Makris, J. Menzel, H. Miller, and R. Vees (1975), Deep seismic soundings in the Afar region and on the highland of Ethiopia, in Afar Depression of Ethiopia, edited by A. Pilger and A. Rösler, pp. 89-107, Schweizerbart, Stuttgart, Germany.

Björnsson, A. (1985), Dynamics of crustal rifting in NE Iceland, J. Geophys. Res., 90, 10,151-10,162, doi:10.1029/JB090iB12p10151.

Björnsson, A., K. Saemundsson, P. Einarsson, E. Tryggvason, and K. Gronvald (1977), Current rifting episode in North Iceland, Nature, 266, 318-323, doi:10.1038/266318a0.

Björnsson, A., G. Johnsen, S. Sigurdsson, G. Thorbergsson, and E. Tryggvason (1979), Rifting of the plate boundary in North Iceland 1975-1978, J. Geophys. Res., 84, 3029-3038, doi:10.1029/ JB084iB06p03029.

Bohnenstiehl, D. R., R. P. Dziak, M. Tolstoy, C. G. Fox, and M. Fowler (2004), Temporal and spatial history of the 1999-2000 Endeavour Segment seismic series, Juan de Fuca Ridge, Geochem. Geophys. Geosyst., 5, Q09003, doi:10.1029/2004GC000735.

Brandsdóttir, B., and P. Einarsson (1979), Seismic activity associated with the September 1977 deflation of Krafla volcano in northeastern Iceland, J. Volcanol. Geotherm. Res., 6, 197-212, doi:10.1016/0377-0273(79) 90001-5.

Brandsdóttir, B., W. Menke, P. Einarsson, R. S. White, and R. K. Staples (1997), Faeroe-Iceland Ridge Experiment: 2. Crustal structure of the Kafla central volcano, J. Geophys. Res., 102, 7867-7886, doi:10.1029/ 96JB03799.

Buck, W. R., L. L. Lavier, and A. N. B. Poliakov (2005), Modes of faulting at mid-ocean ridges, Nature, 434, 719-723, doi:10.1038/nature03358.

Buck, W. R., P. Einarsson, and B. Brandsdóttir (2006), Tectonic stress and magma chamber size as controls on dyke propagation: Constraints from the 1975-1984 Krafla rifting episode, J. Geophys. Res., 111, B12404, doi:10.1029/2005JB003879.

Carmichael, I., J. Nicholls, F. Spera, B. Wood, and S. Nelson (1977), Hightemperature properties of silicate liquids: Applications to the equilibration and ascent of basic magma, Philos. Trans. R. Soc. London, A, 286, 373-431, doi:10.1098/rsta.1977.0124.

Cattin, R., et al. (2005), Numerical modeling of Quaternary deformation and post-seismic displacement in the Asal-Ghoubbet rift (Djibouti, Africa), Earth Planet. Sci. Lett., 239, 352-367, doi:10.1016/j.epsl.2005.07.028.

Cervelli, P., P. Segall, F. Amelung, H. Garbeil, C. Meertens, S. Owen, A. Miklius, and M. Lisowski (2002), The 12 September 1999 Upper East Rift Zone dike intrusion at Kilauea Volcano, Hawaii, J. Geophys. Res. 107(B7), 2150, doi:10.1029/2001JB000602.

Chouet, B., and B. R. Julian (1985), Dynamics of an expanding fluid-filled crack, J. Geophys. Res., 90, 11,187-11,198, doi:10.1029/JB090iB13p11187.

Chouet, B. A., R. A. Page, C. D. Stephens, J. C. Lahr, and J. A. Power (1994), Precursory swarms of long-period events at Redoubt Volcano (1989-1990), Alaska: Their origin and use as a forecasting tool, J. Volcanol. Geotherm. Res., 62, 95-135, doi:10.1016/0377-0273(94)90030-2.

Cochran, J. R. (1983), A model for development of the Red Sea, AAPG Bull., 67, 41-69.

Coté, D. M., K. Kulpinski, C. J. Ebinger, D. Keir, and A. Ayele (2009), Testing models of dike intrusion during rifting episodes: The role of heating in triggering earthquakes in Afar, Eos Trans. AGU, 9(52), Fall Meet. Suppl., Abstract T31B-1820.

Coté, D. M., M. Belachew, A. C. Quillen, C. J. Ebinger, D. Keir, A. Ayele, and T. Wright (2010), Low-frequency hybrid earthquakes near a magma chamber in Afar: Quantifying path effects, Bull. Seismol. Soc. Am., 100, 1892-1903, doi: $10.1785 / 0120090111$.

d'Acremont, E., S. Leroy, M.-O. Beslier, N. Bellahsen, M. Fournier, C. Robin, M. Maia, and P. Gente (2005), Structure and evolution of the eastern Gulf of Aden conjugate margins from seismic reflection data, Geophys. J. Int., 160, 669-690.

Decker, R. W. (1966), Deformation measurements on Kilauea Volcano, Hawaii, Bull. Volcanol., 29, 721-731, doi:10.1007/BF02597190.

Delaney, J. R., D. S. Kelley, M. D. Lilley, D. A. Butterfield, J. A. Baross, W. S. D. Wilcock, R. W. Embley, and M. Summit (1998), The quantum event of oceanic crustal accretion: Impacts of diking at mid-ocean ridges, Science, 281, 222-230, doi:10.1126/science.281.5374.222.

Delaney, P. T., and D. D. Pollard (1982), Solidification of basaltic magma during flow in a dike, Am. $J$. Sci., 282, 856-885, doi:10.2475/ajs. 282.6.856

de Zeeuw-van Dalfsen, E., R. Pedersen, F. Sigmundsson, and C. Pagli (2004), Satellite radar interferometry suggests deep accumulation of magma near the crust-mantle boundary beneath the Krafla volcanic system, Iceland, Geophys. Res. Lett., 31, L13611, doi:10.1029/2004GL020059.

Doubre, C., I. Manighetti, L. Dorbath, C. Dorbath, E. Jacques, and J.-C. Delmond (2007a), Crustal structure and magmato-tectonic processes in an active rift (Asal-Ghoubbet, Afar, East Africa): 1. Insights from a 5-month seismological experiment, J. Geophys. Res., 112, B05405, doi:10.1029/2005JB003940. 
Doubre, C., I. Manighetti, L. Dorbath, C. Dorbath, D. Bertil, and J. C. Delmond (2007b), Crustal structure and magmato-tectonic processes in an active rift (Asal-Ghoubbet, Afar, East Africa): 2. Insights from the 23 -year recording of seismicity since the last rifting event, J. Geophys. Res., 112, B05406, doi:10.1029/2006JB004333.

Dunn, R. A., V. Lekic, R. S. Detrick, and D. R. Toomey (2005), Threedimensional seismic structure of the Mid-Atlantic Ridge $\left(35^{\circ} \mathrm{N}\right)$ : Evidence for focused melt supply and lower crustal dike injection, J. Geophys. Res. 110, B09101, doi:10.1029/2004JB003473.

Dziak, R. P., C. G. Fox, and A. E. Schreiner (1995), The June-July 1993 seismo-acoustic event at Coaxial Segment, Juan de Fuca Ridge: Evidence for a lateral dike injection, Geophys. Res. Lett., 22, 135-138, doi:10.1029/ 94GL01857.

Dziak, R. P., D. K. Smith, D. R. Bohnenstiehl, C. G. Fox, D. Desbruyeres, H. Matsumoto, M. Tolstoy, and D. J. Fornari (2004), Evidence of a recent magma dike intrusion at the slow spreading Lucky Strike segment, Mid-Atlantic Ridge, J. Geophys. Res., 109, B12102, doi:10.1029/ 2004JB003141.

Dziak, R. P., D. R. Bohnenstiehl, H. Matsumoto, M. J. Fowler, J. H. Haxel, M. Tolstoy, and F. Waldhauser (2009), January 2006 seafloor-spreading event at $9^{\circ} 50^{\prime} \mathrm{N}$, East Pacific Rise: Ridge dike intrusion and transform fault interactions from regional hydroacoustic data, Geochem. Geophys. Geosyst., 10, Q06T06, doi:10.1029/2009GC002388.

Ebinger, C. J., D. Keir, A. Ayele, E. Calais, T. J. Wright, M. Belachew, J. O. S. Hammond, E. Campbell, and W. R. Buck (2008), Capturing magma intrusion and faulting processes during continental rupture: Seismicity of the Dabbahu (Afar) rift, Geophys. J. Int., 174, 1138-1152, doi:10.1111/j.1365-246X.2008.03877.x.

Ebinger, C. J., A. Ayele, D. Keir, J. Rowland, G. Yirgu, T. Wright, M. Belachew, and I. Hamling (2010), Length and time scales of rift faulting and magma intrusion: The Afar rifting cycle from 2005 to present, Annu. Rev. Earth Planet. Sci., 38, 437-464.

Einarsson, P. (1978), S-wave shadows in the Krafla caldera in NE-Iceland, evidence for a magma chamber in the crust, Bull. Volcanol., 41, 187-195, doi:10.1007/BF02597222

Einarsson, P. (1991), The Krafla rifting episode 1975-1989, in Náttúra Myvatns, (The Nature of Lake Myvatn), edited by A. Gardarsson and A. Einarsson, pp. 97-139, Icelandic Nat. Sci. Soc., Reykjavik.

Einarsson, P., and B. Brandsdóttir (1980), Seismological evidence for latera magma intrusion during the July 1978 deflation of the Krafla volcano in NE Iceland, J. Geophys. Res., 47, 160-165.

Ferguson, D. J., T. D. Barnie, D. M. Pyle, C. Oppenheimer, G. Yirgu, E. Lewi, T. Kidane, S. Carn, and I. Hamling (2010), Recent rift-related volcanism in Afar, Ethiopia, Earth Planet. Sci. Lett., 292, 409-418, doi:10.1016/j.epsl.2010.02.010.

Fiske, R. S., and W. T. Kinoshita (1969), Inflation of Kilauea volcano prior to its 1967-1968 eruption, Science, 165, 341-349, doi:10.1126/science. 165.3891.341.

Fox, C., W. E. Radford, R. Dziak, T.-K. Lau, H. Matsumoto, and A. E. Schreiner (1995), Acoustic detection of a seafloor spreading episode on the Juan de Fuca ridge using military hydrophone arrays, Geophys. Res. Lett., 22, 131-134, doi:10.1029/94GL02059.

Grandin, R., et al. (2009), September 2005 Manda Hararo-Dabbahu rifting event, Afar (Ethiopia): Constraints provided by geodetic data, J. Geophys. Res., 114, B08404, doi:10.1029/2008JB005843.

Grandin, R., A. Socquet, E. Jacques, N. Mazzoni, J.-B. de Chabalier, and G. C. P. King (2010a), Sequence of rifting in Afar, Manda-Hararo rift, Ethiopia, 2005-2009: Timespace evolution and interactions between dikes from interferometric synthetic aperture radar and static stress change modeling, J. Geophys. Res., 115, B10413, doi:10.1029/ 2009JB000815

Grandin, R., A. Socquet, M.-P. Doin, E. Jacques, J.-B. de Chabalier, and G. C. P. King (2010b), Transient rift opening in response to multiple dike injections in the Manda Hararo rift (Afar, Ethiopia) imaged by timedependent elastic inversion of InSAR data, J. Geophys. Res., 115 , B09403, doi:10.1029/2009JB006883.

Gutenberg, B., and C. F. Richter (1956), Earthquake magnitude, intensity, energy, and acceleration, Bull. Seismol. Soc. Am., 46, 105-145.

Hamling, I. J. (2010), Measuring and modeling deformation during the Dabbahu (Afar) rifting episode, Ph.D. dissertation, Univ. of Leeds, Leeds, U. K.

Hamling, I. J., A. Ayele, L. Bennati, E. Calais, C. J. Ebinger, D. Keir, E. Lewi, T. J. Wright, and G. Yirgu (2009), Geodetic observations of the ongoing Dabbahu rifting episode: New dyke intrusions in 2006 and 2007 , Geophys. J. Int., 178, 989-1003, doi:10.1111/j.1365-246X.2009.04163.x.

Hamling, I. J., T. J. Wright, E. Calais, L. Bennati, and E. Lewi (2010), Stress transfer between thirteen successive dyke intrusions in Ethiopia, Nat. Geosci., 3, 713-717, doi:10.1038/ngeo967.
Hautot, S., K. A. Whaler, M. Desissa, G. Dawes, S. Fisseha, and N. Johnson (2009), 3-D conductivity structure of an active magmatic segment associated with the final stage of continental break-up: Afar, Ethiopia, Eos Trans. AGU, 90(52), Fall Meet. Suppl., Abstract T43F-07.

Hayward, N. J., and C. J. Ebinger (1996), Variations in the along-axis segmentation of the Afar Rift System, Tectonics, 15, 244-257.

Hofstetter, R., and M. Beyth (2003), The Afar Depression: Interpretation of the 1960-2000 earthquakes, Geophys. J. Int., 155, 715-732, doi:10.1046/j.1365-246X.2003.02080.x.

Ida, Y. (1999), Effects of the crustal stress on the growth of dikes: Conditions of intrusion and extrusion of magma, J. Geophys. Res., 104, 17,897-17,909, doi:10.1029/1998JB900040.

Jacques, E., G. C. P. King, P. Tapponnier, J. C. Ruegg, and I. Manighetti (1996), Seismic activity triggered by stress changes after the 1978 events in the Asal Rift, Djibouti, Geophys. Res. Lett., 23, 2481-2484, doi:10.1029/96GL02261.

Keir, D., G. W. Stuart, A. Jackson, and A. Ayele (2006), Local earthquake magnitude scale and seismicity rate for the Ethiopian rift, Bull. Seismol. Soc. Am., 96, 2221-2230, doi:10.1785/0120060051.

Keir, D., et al. (2009), Evidence for focused magmatic accretion at segment centers from lateral dike injections captured beneath the Red Sea rift in Afar, Geology, 37, 59-62, doi:10.1130/G25147A.1.

Kidd, R. G. W. (1977), A model for the process of formation of the upper oceanic crust, Geophys. J. R. Astron. Soc., 50(1), 149-183.

Kinoshita, W. T., D. A. Swanson, and D. B. Jackson (1974), The measurement of crustal deformation related to volcanic activity at Kilauea volcano, Hawaii, in Physical Volcanology, edited by L. Civette et al. pp. 87-115, Elsevier, New York.

Kissling, E., U. Kradolfer, and H. Maurer (1995), VELEST User's Guide: Short Introduction, Inst. of Geophys. and Swiss Seismol. Serv., ETH Zurich, Zurich, Switzerland.

Klein, F. W. (2002), User's guide to Hypoinverse-2000, a FORTRAN program to solve for earthquake locations and magnitudes, U.S. Geol. Surv. Open File Rep., 02-171, 1-123.

Klein, F. W., R. Y. Koyanagi, J. S. Nakata, and W. R. Tanigawa (1987), The seismicity of Kilauea's magma system, in Volcanism in Hawaii, edited by R. W. Decker et al., U.S. Geol. Surv. Prof. Pap., 1350, 961-996.

Lahitte, P., P.-Y. Gillot, T. Kidane, V. Courtillot, and A. Bekele (2003), New age constraints on the timing of volcanism in central Afar, in the presence of propagating rifts, J. Geophys. Res., 108(B2), 2123, doi:10.1029/2001JB001689.

Lahr, J. C., B. A. Chouet, C. D. Stephens, J. A. Power, and R. A. Page (1994), Earthquake classification, location, and error analysis in a volcanic environment: Implications for the magmatic system of the 1989-1990 eruptions at Redoubt Volcano, Alaska, J. Volcanol. Geotherm. Res., 62, 137-151, doi:10.1016/0377-0273(94)90031-0.

Lister, J. R., and R. C. Kerr (1991), Fluid-mechanical models of crack propagation and their application to magma transport in dykes, J. Geophys. Res., 96, 10,049-10,077, doi:10.1029/91JB00600.

Macdonald, K. C. (1998), Linkages between faulting, volcanism, hydrothermal activity and segmentation on fast spreading centers, in Faulting and Magmatism at Mid-Ocean Ridges, Geophys. Monogr. Ser, vol. 106, edited by W. R. Buck et al., pp. 27-58, AGU, Washington, D. C.

Makris, J., and A. Ginzburg (1987), The Afar Depression: Transition between continental rifting and seafloor spreading, Tectonophysics, 141, 199-214, doi:10.1016/0040-1951(87)90186-7.

Manighetti, I., P. Tapponnier, V. Courtillot, S. Gruszow, and P.-Y. Gillot (1997), Propagation of rifting along the Arabia-Somalia plate boundary: The gulfs of Aden and Tadjoura, J. Geophys. Res., 102, 2681-2710, doi:10.1029/96JB01185.

Manighetti, I., P. Tapponnier, P. Y. Gillot, E. Jacques, V. Courtillot, R. Armijo, J. C. Ruegg, and G. King (1998), Propagation of rifting along the Arabia-Somalia plate boundary: Into Afar, J. Geophys. Res., 103, 4947-4974, doi:10.1029/97JB02758.

Manighetti, I., P. Tapponnier, V. Courtillot, Y. Gallet, E. Jacques, and Y. Gillot (2001), Strain transfer between disconnected, propagating rifts in Afar, J. Geophys. Res., 106, 13,613-13,665, doi:10.1029/2000JB900454.

McClusky, S., et al. (2010), Kinematics of the southern Red Sea-Afar Triple Junction and implications for plate dynamics, Geophys. Res. Lett., 37, L05301, doi:10.1029/2009GL041127.

McKenzie, D. P., D. Davis, and P. Molnar (1970), Plate tectonics of the Red Sea and East Africa, Nature, 226, 243-248, doi:10.1038/226243a0. McNutt, S. R. (2005), A review of volcanic seismology, Annu. Rev. Earth Planet. Sci., 33, 461-491, doi:10.1146/annurev.earth.33.092203.122459. Mohr, P. (1967), Major volcanotectonic lineament in the Ethiopian rift system, Nature, 213, 664-665, doi:10.1038/213664a0.

Moore, J. G., and H. L. Krivoy (1964), The 1962 flank eruption of Kilauea Volcano and structure of the east rift zone, J. Geophys. Res., 69, 2033-2045, doi:10.1029/JZ069i010p02033. 
Okamura, A. T., J. J. Dvorak, R. Y. Koyanagi, and W. T. Tanigawa (1988), Surface deformation during dike propagation, in The Pu'u 0'o Eruption of Kilauea Volcano, Hawaii: Episodes 1 through 20, January 3, 1983 , through June 8, 1984, edited by E.W. Wolfe, U.S. Geol. Surv. Prof. Pap., 1463, 165-181.

Owen, S., P. Segall, M. Lisowski, A. Miklius, R. Denlinger, and M. Sako (2000), Rapid deformation of Kilauea Volcano: Global positioning system measurements between 1990 and 1996, J. Geophys. Res., 105, 18,983-18,998, doi:10.1029/2000JB900109.

Pasteris, J. (1984), Kimberlites: Complex mantle melts, Annu. Rev. Earth Planet. Sci., 12, 133-153, doi:10.1146/annurev.ea.12.050184.001025.

Pedersen, R., F. Sigmundsson, and P. Einarsson (2007), Controlling factors on earthquake swarms associated with magmatic intrusions: Constraints from Iceland, J. Volcanol. Geotherm. Res., 162, 73-80, doi:10.1016/j. jvolgeores.2006.12.010.

Pinel, V., and C. Jaupart (2004), Magma storage and horizontal dyke injection beneath a volcanic edifice, Earth Planet. Sci. Lett., 221, 245-262, doi:10.1016/S0012-821X(04)00076-7.

Rivalta, E. (2010), Evidence that coupling to magma chambers controls the volume history and velocity of laterally propagating intrusions, J. Geophys. Res., 115, B07203, doi:10.1029/2009JB006922.

Rivalta, E., and P. Segall (2008), Magma compressibility and the missing source for some dike intrusions, Geophys. Res. Lett., 35, L04306, doi:10.1029/2007GL032521.

Rowland, J. V., et al. (2007), Fault growth at a nascent slow spreading ridge: 2005 Dabbahu rifting episode, Afar, Geophys. J. Int., 171, 1226-1246, doi:10.1111/j.1365-246X.2007.03584.x.

Rubin, A. M. (1992), Dike-induced faulting and graben subsidence in volcanic rift zones, J. Geophys. Res., 97, 1839-1858, doi:10.1029/ 91JB02170.

Rubin, A. M. (1995), Propagation of magma-filled cracks, Annu. Rev. Earth Planet. Sci., 23, 287-336, doi:10.1146/annurev.ea.23.050195.001443.

Rubin, A. M., and D. Gillard (1998), Dike-induced earthquakes: Theoretical considerations, J. Geophys. Res., 103, 10,017-10,030, doi:10.1029/ 97JB03514.

Rubin, A. M., and D. D. Pollard (1988), Dike-induced faulting in rift zones of Iceland and Afar, Geology, 16, 413-416, doi:10.1130/00917613(1988)016<0413:DIFIRZ>2.3.CO;2.

Rubin, A., D. Gillard, and J. Got (1998), A reinterpretation of seismicity associated with the January 1983 dike intrusion at Kilauea volcano, Hawaii, J. Geophys. Res., 103, 10,003-10,015, doi:10.1029/97JB03513.

Ruegg, J.-C. (1975), Structure profonde de la croute et du manteau superieur du Sud-Est de l'Afar d'apres les donnees sismiques, Ann. Geophys. 31, 329-360.

Segall, P., P. Cervelli, S. Owen, M. Lisowski, and A. Miklius (2001), Constraints on dike propagation from continuous GPS measurements, J. Geophys. Res., 106, 19,301-19,317, doi:10.1029/2001JB000229.

Spera, F. (1980), Aspects of magma transport, in Physics of Magmatic Processes, edited by R. B. Hargraves, pp. 232-265, Princeton Univ. Press, Princeton, N. J.

Stammler, K. (1993), Seismic Handler: Programmable multichannel data handler for interactive and automatic processing of seismological analyses, Comput. Geosci., 19, 135-140, doi:10.1016/0098-3004(93)90110-Q.

Takada, A. (1997), Cyclic flank-vent and central-vent eruption patterns, Bull. Volcanol., 58, 539-556, doi:10.1007/s004450050161.
Toda, S., R. S. Stein, and T. Sagiya (2002), Evidence from the AD 2000 Izu islands earthquake swarm that stressing rate governs seismicity, Nature, 419, 58-61, doi:10.1038/nature00997.

Tolstoy, M., et al. (2006), A sea-floor spreading event captured by seismometers, Science, 314, 1920-1922, doi:10.1126/science.1133950.

Toutain, J., P. Bachelery, P. Blum, J. Cheminee, H. Delorme, L. Fontaine, P. Kowalski, and P. Taochy (1992), Real time monitoring of vertical ground deformations during eruptions at Piton de la Fournaise, Geophys. Res. Lett., 19, 553-556, doi:10.1029/91GL00438.

Traversa, P., and J. Grasso (2009), Brittle creep damage as the seismic signature of dyke propagations within basaltic volcanoes, Bull. Seismol. Soc. Am., 99, 2035-2043, doi:10.1785/0120080275.

Traversa, P., V. Pinel, and J. R. Grasso (2010), A constant influx model for dike propagation: Implications for magma reservoir dynamics, J. Geophys. Res., 115, B01201, doi:10.1029/2009JB006559.

Tryggvason, E. (1980), Subsidence events in the Krafla area, north Iceland, 1975-1979, J. Geophys., 47, 141-153

Tryggvason, E. (1984), Widening of the Krafla fissure swarm during the 1975-1981 volcano-tectonic episode, Bull. Volcanol., 47(1), 47-69, doi:10.1007/BF01960540.

Varet, J. (1978), Geology of Central and Southern Afar (Ethiopia and Djibouti Republic), map, 1:500,000, Cent. Natl. de la Recherche Sci., Paris.

Wessel, P., and W. H. F. Smith (1998), New, improved version of generic mapping tools released, Eos Trans. AGU, 79, 579, doi:10.1029/ 98EO00426.

Williams, A., R. Pik, P. Burnard, S. Medynski, and G. Yirgu (2009), Tectonic-magmatic interplay during the early stages of oceanic rifting Temporal constraints from cosmogenic 3He dating in the Dabbahu rift segment, Afar, Eos Trans. AGU, 90(52), Fall Meet. Suppl., Abstract T31B-1816.

Wolfenden, E., C. Ebinger, G. Yirgu, P. R. Renne, and S. P. Kelly (2005) Evolution of a volcanic rifted margin: Southern Red Sea, Ethiopia, Geol. Soc. Am. Bull., 117, 846-864, doi:10.1130/B25516.1.

Wright, T. J., C. Ebinger, J. Biggs, A Ayele, G. Yirgu, D. Keir, and A. Stork (2006), Magma maintained rift segmentation at continental rupture in the 2005 Afar dyking episode, Nature, 442, 291-294, doi:10.1038/ nature 04978 .

Yamaoka, K., M. Kawamura, F. Kimata, N. Fujii, and T. Kudo (2005), Dike intrusion associated with the 2000 eruption of Miyakejima Volcano, Japan, Bull. Volcanol., 67, 231-242, doi:10.1007/s00445-004-0406-2.

Yirgu, G. (2007), The August 2007 fissure eruption on the Dabbahu rift segment, paper presented at 26th Workshop on Active Volcanism Continental Rifting, Eur. Cent. for Geodyn. and Seismol, Luxembourg.

A. Ayele, Institute of Geophysics, Space Science and Astronomy, Addis Ababa University, PO Box 1176, Addis Ababa, Ethiopia.

M. Belachew, D. Coté, and C. Ebinger, Department of Earth and Environmental Sciences, University of Rochester, Rochester, NY 14627 USA. (manahloh@earth.rochester.edu)

J. O. S. Hammond, Department of Earth Science, University of Bristol, Bristol BS8 1RJ, UK.

D. Keir, School of Earth and Environment, University of Leeds, Leeds LS2 9JT, UK

J. V. Rowland, School of Environment, University of Auckland, Private Bag 92019, Auckland 1142, New Zealand. 